\title{
Amyloid Oligomers Exacerbate Tau Pathology in a Mouse Model of Tauopathy
}

\author{
Maj-Linda B. Selenica ${ }^{a}$ Milene Brownlow ${ }^{a}$ Jeffy P. Jimenez ${ }^{c}$ Daniel C. Lee ${ }^{d}$ \\ Gabriela Pena ${ }^{a}$ Chad A. Dickey ${ }^{b}$ Marcia N. Gordon ${ }^{a}$ Dave Morgana \\ Departments of a Molecular Pharmacology and Physiology, ${ }^{b}$ Molecular Medicine, USF Health Byrd Alzheimer's \\ Institute, University of South Florida, ' Department of Bioengineering, University of South Florida, and ${ }^{\mathrm{d}}$ Department of \\ Pharmaceutical Sciences, USF Health, College of Pharmacy, Tampa, Fla., USA
}

\section{Key Words}

$\beta$-Amyloid • Glycogen synthase kinase $3 \alpha / \beta$. Inflammation - Microglia • Microosmotic pump • Phosphorylation · Tau

\begin{abstract}
Background: We aimed to investigate the influence of oligomeric forms of $\beta$-amyloid $(A \beta)$ and the influence of the duration of exposure on the development of tau phosphorylation. Methods: A $\beta$ oligomers were injected intracranially either acutely into 5-month-old rTg4510 mice and tissue was collected 3 days later, or chronically into 3-month-old mice and tissue was collected 2 months later. Several forms of phosphorylated tau (p-tau), GSK3 (glycogen synthase kinase-3) and microglial and astrocyte activation were measured. Results: Acute injections of $A \beta$ oligomers had no effect on $p$-tau epitopes but did result in elevation of phosphorylated/activated GSK3 (pGSK3). Chronic infusion of $A \beta$ oligomers into the right hippocampus resulted in 3- to 4-fold elevations in several $p$-tau isoforms with no changes in total tau levels. A significant elevation in pGSK3 accompanied these changes. Microglial staining with CD68 paralleled the increase in tau phosphorylation, however, CD45 staining was unaffected by $A \beta$. Control experiments revealed that the infusion of $A \beta$ from the minipumps was largely complete
\end{abstract}

by 10 days after implantation. Thus, the elevation in $\mathrm{p}$-tau 2 months after implantation implies that the changes are quite persistent. Conclusion: Soluble $A \beta_{1-42}$ oligomers have longlasting effects on tau phosphorylation in the rTg4510 model, possibly due to elevations in GSK3. These data suggest that even brief elevations in $A \beta$ production, may have enduring impact on the risk for tauopathy.

Copyright $\odot 2012$ S. Karger AG, Basel

\section{Introduction}

In Alzheimer's disease (AD) and other tauopathy disorders, tau is involved in a series of pathological events, including hyperphosphorylation and aggregation into straight and paired helical filaments [1], and finally, the formation of neurofibrillary tangles (NFT). The consequence of this process is disruption of microtubule assembly [2] and axonal transport [3,4], which ultimately may lead to neurodegeneration.

Transgenic mouse models expressing human tau mutations develop pathology that mimics frontotemporal dementia with parkinsonism linked to chromosome 17 (FTDP-17) disorder, and have improved understanding of tau-mediated neurodegeneration [5,6]. The inducible rTg4510 mouse model used here has demonstrated pro-

\section{KARGER \\ Fax +4161306 1234 \\ E-Mail karger@karger.ch}

www.karger.com (c) 2012 S. Karger AG, Basel

$1660-2854 / 13 / 0114-0165 \$ 38.00 / 0$

Accessible online at:

www.karger.com/ndd
Dave Morgan, $\mathrm{PhD}$

Byrd Alzheimer's Institute, University of South Florida

4001 East Fletcher Avenue

Tampa, FL 33613 (USA)

Tel. +1 813974 3949, E-Mail scientist.dave@gmail.com 
gression of tau pathology with age, the formation of neurofibrillary tangles, cognitive impairment and neuronal loss $[7,8]$. Understanding the mechanisms of cross-talk between tau and $\beta$-amyloid $(A \beta)$ has moved this area to the center of research efforts. It is still unclear in the literature whether the human amyloid precursor protein (hAPP)/A $\beta$ pathology is responsible for tau pathology in AD. Reports from studies of transgenic mouse models suggest that manipulation of $A \beta$ levels drives changes in the tau pathology [9-11]. Notably, the role of AD brainderived and synthetically prepared $A \beta$ oligomers in causing early synaptic toxicity $[12,13]$, long-term potentiation deficits $[14,15]$ and cognitive dysfunction [16] supports a direct role of $A \beta_{1-42}$-derived oligomers in the early pathology of disease. However, other reports suggest that reduction of endogenous tau levels protects against excitotoxicity in vitro [17] and prevents $A \beta$-related behavioral deficits in transgenic mice expressing human APP, potentially via tyrosine kinase Fyn activation [18, 19]. Moreover, a dendritic role of tau in conferring Fyn-mediated $A \beta$ toxicity was suggested as a possible mechanistic explanation of the $A \beta$, tau and Fyn triad [20].

In the present study, we examined the effect of acute or chronically infused synthetic oligomeric $A \beta_{1-42}$ on phosphorylated (p)-tau levels in 5-month-old rTg4510 mice. The questions we wished to address concerned (a) the dwell time of oligomeric $A \beta$ after intracranial administration, (b) the impact of the $A \beta$ oligomers on tau metabolism and its persistence in the early stages of tauopathy and (c) the relationship of these changes to kinase activity and microglial activation. Our findings are consistent with the accumulating body of evidence that $A \beta$ oligomers exacerbate tau pathology in vivo.

\section{Materials and Methods}

Production and SDS-PAGE/Immunoblotting of Oligomers

Oligomers of $A \beta_{1-42}$ were prepared as described previously [21]. For initial characterization, $A \beta_{1-42}$ peptide (Biosource, Camarillo, Calif., USA) was dissolved in ice-cold hexafluoroisopropanol and thoroughly mixed. Aliquots were taken, the hexafluoroisopropanol was completely evaporated, and samples were frozen at $-80^{\circ} \mathrm{C}$ until use. For oligomer preparations, the dried $\mathrm{A} \beta$ was first dissolved in $100 \%$ DMSO to $5 \mathrm{mM} \mathrm{A} \beta$, then 50 -fold diluted with F12 medium (PromoCell, Heidelberg, Germany) supplemented with $146 \mathrm{mg} / \mathrm{l}$ glutamine (PromoCell) to obtain 100 $\mu \mathrm{M}$ of $\mathrm{A} \beta$ solution. Samples were incubated for $24 \mathrm{~h}$ at $4^{\circ} \mathrm{C}$ and then centrifuged at $14,000 \mathrm{~g}$ for $10 \mathrm{~min}$ at $4^{\circ} \mathrm{C}$ to remove large aggregates. The size distribution of the oligomers in the supernatant was examined by atomic force microscopy (AFM).

The 100- $\mu \mathrm{MA} \beta_{1-42}$ sample prepared as described above was incubated for 30 days inside a microosmotic pump (Alzet No.
1004; Durect, Cupertino, Calif., USA) at $37^{\circ} \mathrm{C}$ in PBS (pH 7.4). Due to the properties of the osmotic pump, we were able to collect aliquots of oligomers pumped from the reservoir at various time points. Aliquots were diluted 10 -fold, and applied to SDS-PAGE as previously described [22]. Monoclonal mouse antibody 6E10 against $\mathrm{A} \beta$ was used (Convance, Dedham, Mass., USA; 1:1,000 dilution). Immunostained proteins were visualized using chemiluminescence, in accordance with the manufacturer's recommendations (ECL; SignaGen Laboratories, Gaithersburg, Md., USA).

\section{Physical Characterization of the Oligomeric Solution}

AFM (XE-100; PSIA, Santa Clara, Calif., USA) was used to determine the morphology of the species present in the $A \beta_{1-42}$ oligomeric solution. Silicon nitride with aluminum coating (Tap300Al-G; Budget Sensors, Sofia, Bulgaria) cantilevers with $300-\mathrm{kHz}$ frequency and $40 \mathrm{~N} / \mathrm{m}$ force constant were used in this study. The images were collected at a scan rate of $1 \mathrm{~Hz} / \mathrm{min}$ and gain 1. Five microliters of the oligomeric solution were deposited on freshly cleaved mica at a concentration of $25 \mu \mathrm{M}$, incubated for $5 \mathrm{~min}$, rinsed with Millipore water and dried with ultrapure nitrogen (NI UHP300; Airgas, Tampa, Fla., USA). The samples were imaged using tapping mode to preserve their integrity.

\section{Mice}

The rTg4510 mice originate from the mouse model of tauopathy described elsewhere [8]. Both rTg4510 mice and the littermate control mice that do not express tau were used between 3 and 5 months of age. Animals were housed and treated according to institutional and National Institutes of Health standards.

Stereotaxic Intracranial Injections and Infusion of $A \beta_{1-42}$ Oligomers

Acute injections of $100 \mu \mathrm{M}$ of oligomers or scramble $A \beta_{1-42}$ into the cortex and hippocampus of 5-month-old $\mathrm{rTg} 4510$ and age-matched nontransgenic (ntg) littermates were performed using the convection-enhanced delivery method described previously [23]. The injection coordinates were as follows: hippocampus, anteroposterior, $-2.7 \mathrm{~mm}$; lateral $-2.7 \mathrm{~mm}$, vertical $-3.0 \mathrm{~mm}$ from bregma; cortex, anteroposterior, $+1.7 \mathrm{~mm}$; lateral $-2.2 \mathrm{~mm}$, vertical $-3.0 \mathrm{~mm}$ from bregma. Ntg mice injected with oligomers were sacrificed $1 \mathrm{~h}$ after intracranial injection to visualize the injected material, while rTg4510 injected with oligomers or scrambled $A \beta_{1-42}$ survived for 3 days. The chronic infusion of human $A \beta_{1-42}$ oligomers or saline into 3-month-old rTg4510 and ntg mice was performed as described previously [24]. Briefly, a cannulae (Plastics One, Roanoke, Va., USA) was stereotactically implanted into the right hippocampus (coordinates from bregma: $-2.7 \mathrm{~mm}$ anteroposterior; $-2.7 \mathrm{~mm}$ lateral; $3.0 \mathrm{~mm}$ vertical), and an osmotic pump (Alzet No. 1004; Durect, Cupertino, Calif., USA) was attached and implanted subcutaneously near the scapula. Pumps contained either oligomeric $A \beta_{1-42}$ (Biosource) in vehicle (F12 medium) or saline alone. The infusion rate was $0.11 \mu \mathrm{l} / \mathrm{h}(67 \mathrm{ng} / \mathrm{h}$ $\left.A \beta_{1-42}\right)$. Pumps remained in place for $A \beta$ delivery for 28 days, and mice were sacrificed 1 month after the termination of the infusion (2 months after pump placement).

\section{Immunohistochemistry/Immunofluorescence}

Immunohistochemistry was performed on free-floating sections collected from brain tissue and prepared as described in detail previously [25]. Sections were incubated with primary an- 
Table 1. Antibodies used for immunohistochemistry and immunofluorescence

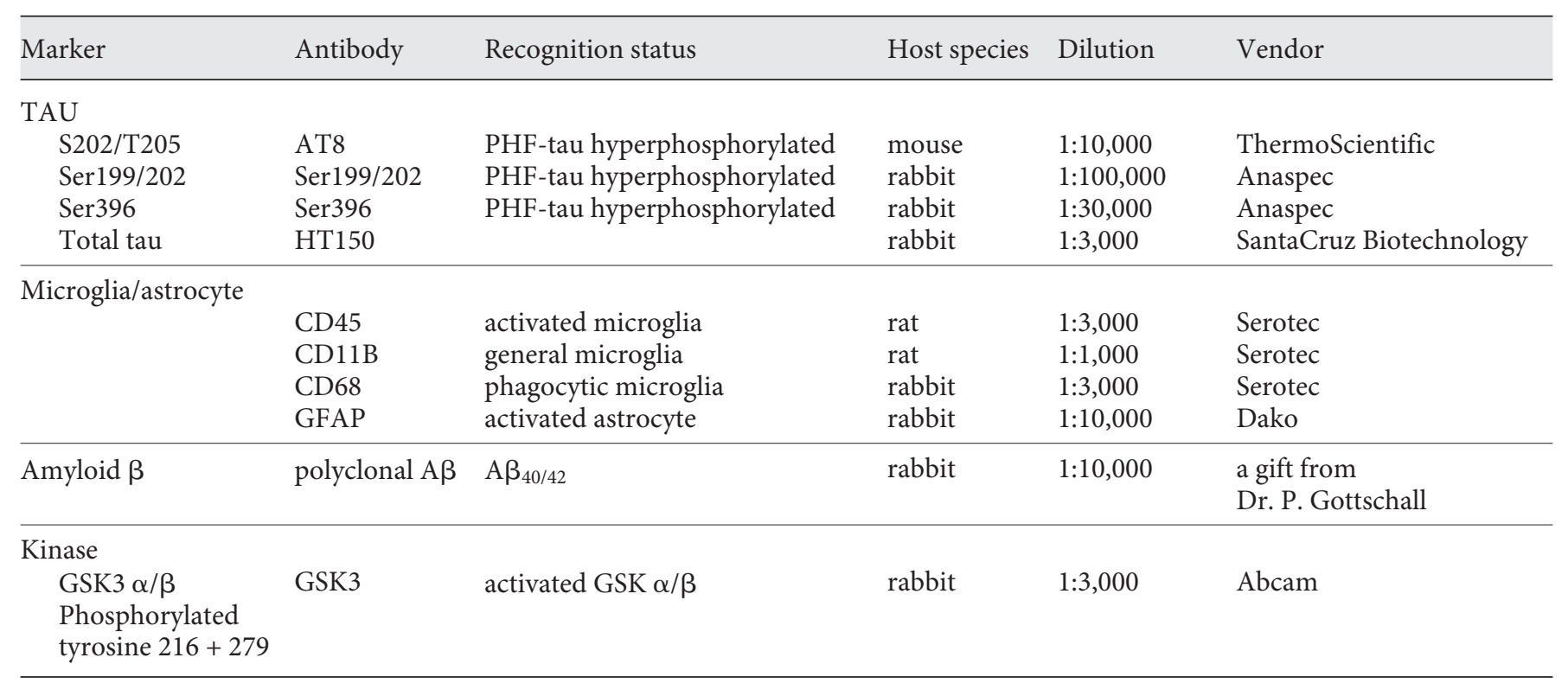

tibodies (table 1) overnight at $4{ }^{\circ} \mathrm{C}$, washed and incubated with either goat anti-rabbit IgG Alexa 594, streptavidin-Alexa 488 (Invitrogen, Carlsbad, Calif., USA) for immunofluorescence or with the appropriate biotinylated secondary antibody for immunohistochemistry (Vector Laboratories, Burlingame, Calif., USA) for $2 \mathrm{~h}$ at room temperature. For immunohistochemistry, sections were incubated for $1 \mathrm{~h}$ in avidin-biotin complex (Vectastain Elite; Vector Laboratories) and washed. Color development was performed using 3,3'-diaminobenzidine (DAB; Sigma, St. Louis, Mo., USA) enhanced with nickelous ammonium sulfate (Baker, Phillipsburg, N.J., USA). Staining was analyzed with a digital scanning microscope (Mirax) and quantified by the Zeiss Image HIS segmentation analyzing program (Zeiss, Göttingen, Germany). For immunofluorescence, sections were mounted on slides and imaged using a Zeiss AxioVision Imager Z1 microscope and processed using AxioVision 4.8 image software.

\section{Statistics}

Statistical analyses were performed using Student's t test or one-way ANOVA followed by Fisher's post hoc least-significant difference (PLSD) test for the comparison of means using StatView software (version 5.0; SAS Institute, Cary, N.C., USA). Graphs were generated using GraphPad Prism 4.0 (La Jolla, Calif., USA).

\section{Results}

\section{$A \beta_{1-42}$ Oligomer Characterization}

Based on results suggesting a link between amyloid and tau pathology $[10,26,27]$, we administered oligomers of $A \beta_{1-42}$ into rTg4510 mice. Oligomeric species were pre- pared using defined conditions described previously [21]. Western blotting and AFM were used to determine the secondary structure of $A \beta_{1-42}$-derived oligomers. Figure 1a shows the bands identified on the SDS-PAGE and Western blot. The preparation contains a mixture of low (LMW, 17-14 kDa) and high-molecular-weight oligomers (HMW, 38-180 kDa) as well as the monomer. We exploited AFM to investigate the physical features of the oligomers after a 24 -hour incubation at $37^{\circ} \mathrm{C}$. As shown in figure $1 \mathrm{~b}$, most of the 24 -hour incubation samples contained globular structures with a mean diameter of 22 $\mathrm{nm}$ and a height of $2.8 \mathrm{~nm}$.

\section{$A \beta_{1-42}$ Oligomers after Injection into the Mouse CNS}

To monitor the distribution of $A \beta$ oligomers after injection into mouse brain, we performed acute injections into the anterior cortex and hippocampus unilaterally and monitored the dispersion of the injected material using immunohistochemistry. When tissue was collected $1 \mathrm{~h}$ after the intracerebral injection, we found extensive diffusion of $A \beta$ from the sites of injection (arrowheads, fig. 2a) with some distribution into the striatum after cortical injection and to the entorhinal cortex after hippocampal injection. There was no immunostaining visible in the uninjected hemisphere (left, fig. $2 \mathrm{~b}$ ), suggesting that the injected material did not cross the midline. However, in tissue collected 3 days after the acute injection, we were unable to detect $A \beta$ oligomers in any brain region (fig. $2 b$ ). 


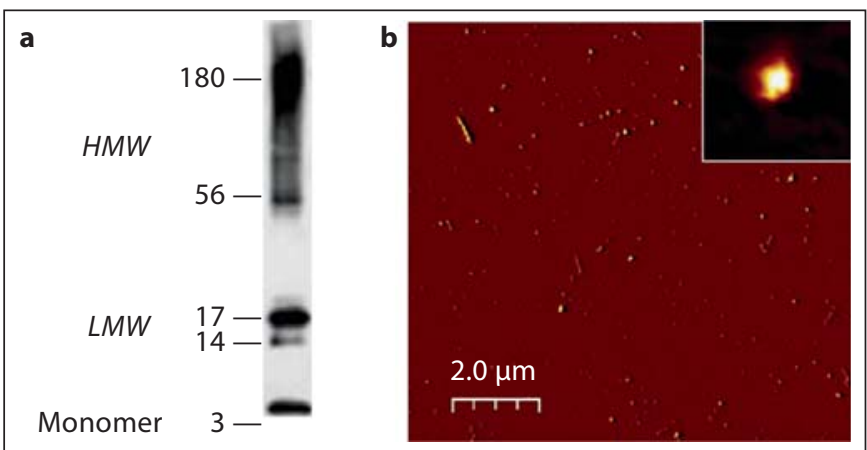

Fig. 1. Biophysical characterization of oligomer preparations. a $100 \mu \mathrm{M}$ of $\mathrm{A} \beta_{42}$-derived oligomers were prepared as described in the Materials and Methods section and subjected to SDS-PAGE and Western blot using the $6 \mathrm{E} 10$ antibody. Monomers $(4.5 \mathrm{kDa})$, LMW ranging from $14-17 \mathrm{kDa}$ and $\mathrm{HMW}$ between $38-180 \mathrm{kDa}$ are visible. b AFM image of the $100 \mu \mathrm{M}$ of stock concentration of oligomers incubated for $24 \mathrm{~h}$ at $37^{\circ} \mathrm{C}$. The globular structure of oligomers was observed in a $10 \times 10 \mu \mathrm{m} x-y$ scan size (the maximum height in the $\mathrm{z}$-axis is $10 \mathrm{~nm}$ ). The inset represents a higher magnification of an oligomer with a diameter of $22 \mathrm{~nm}$ and a height of $2.78 \mathrm{~nm}$.

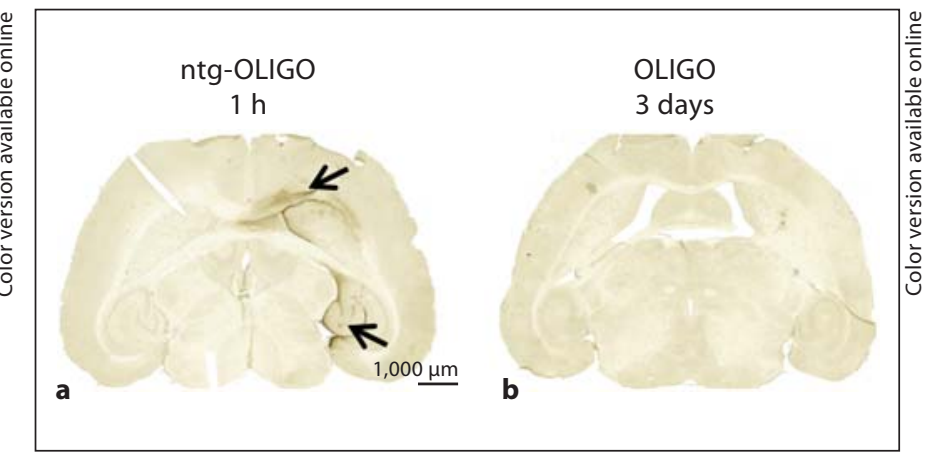

Fig. 2. Detection of $A \beta_{42}$ in the brain after acute intracerebral injection of oligomers (OLIGO): $100 \mu \mathrm{M}$ of $\mathrm{A} \beta_{42}$-derived OLIGO were injected in the cortex and hippocampus of ntg mice for $1 \mathrm{~h}$ (a) arrows indicating the injection sites, $\mathrm{n}=3$ ); $100 \mu \mathrm{M}$ of OLIGO was injected in brain regions of $\mathrm{rTg} 4510$ mice for 3 days $(\mathbf{b} ; n=5)$. Tissue was stained for A $\beta$ immunoreactivity.

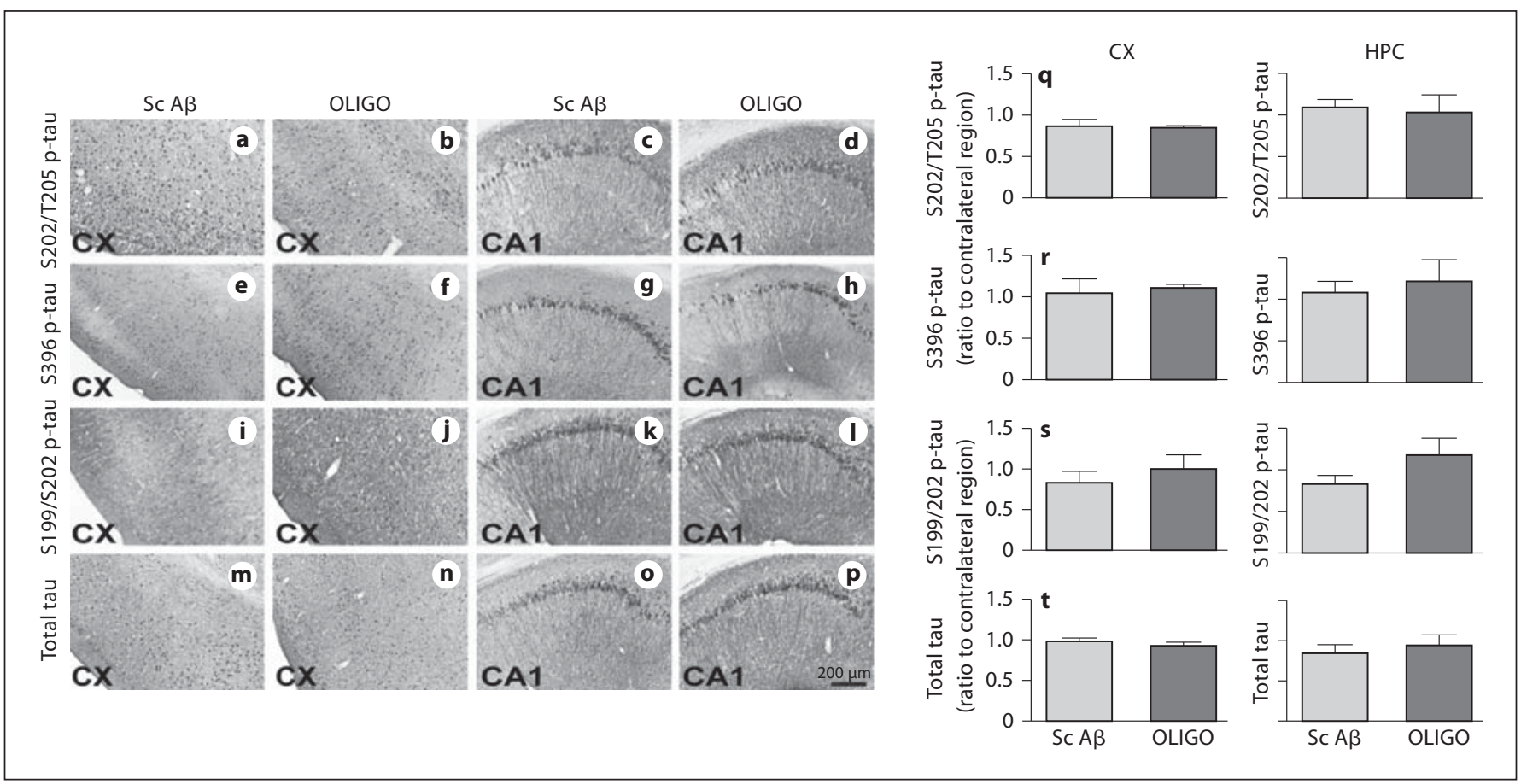

Fig. 3. Acute injection of oligomers (OLIGO) did not affect p-tau levels. Immunoreactivity of S202/T205, S396, S199/S202 p-tau and total tau immunoreactivity in the ipsilateral frontal cortex (CX) and CA1 field of the hippocampus (a-p) of rTg4510 mice injected with scrambled $(\mathrm{Sc}) \mathrm{A} \beta(\mathrm{n}=5)$ or OLIGO $(\mathrm{n}=5)$ are shown. The levels of total tau or $\mathrm{p}$-tau were undetectable in the ntg mice injected with OLIGO preparations and hence were not shown. Staining intensity was analyzed as percent of stained area for each region and represented as ratio of the ipsilateral to contralateral side $(\mathbf{q}-\mathbf{t})$. Data from the frontal CX are presented on the left, while data from the hippocampus (HPC) are presented on the right. There were no statistically significant changes in staining for any tau marker. Statistical comparisons by Student's t test were performed using StatView software. 
Fig. 4. GSK3 activation occurred following acute injection of oligomers (OLIGO) but not scrambled (Sc) A $\beta$. pGSK3 $\alpha / \beta$ immunoreactivity in the frontal cortex $(\mathrm{CX})$ and CA1 (hippocampus, HPC) of rTg4510 Sc $\mathrm{A} \beta(\mathbf{a}, \mathbf{b})$ or OLIGO $(\mathbf{c}, \mathbf{d})$ is presented. Staining intensity was analyzed as percent of stained area and presented as ratio of the ipsilateral to the contralateral side for each region after treatment $(\mathbf{e}, \mathbf{f})$. Student's t-test: ${ }^{*} \mathrm{p}<0.05 ;{ }^{*} \mathrm{p}<0.01, \mathrm{n}=5$.
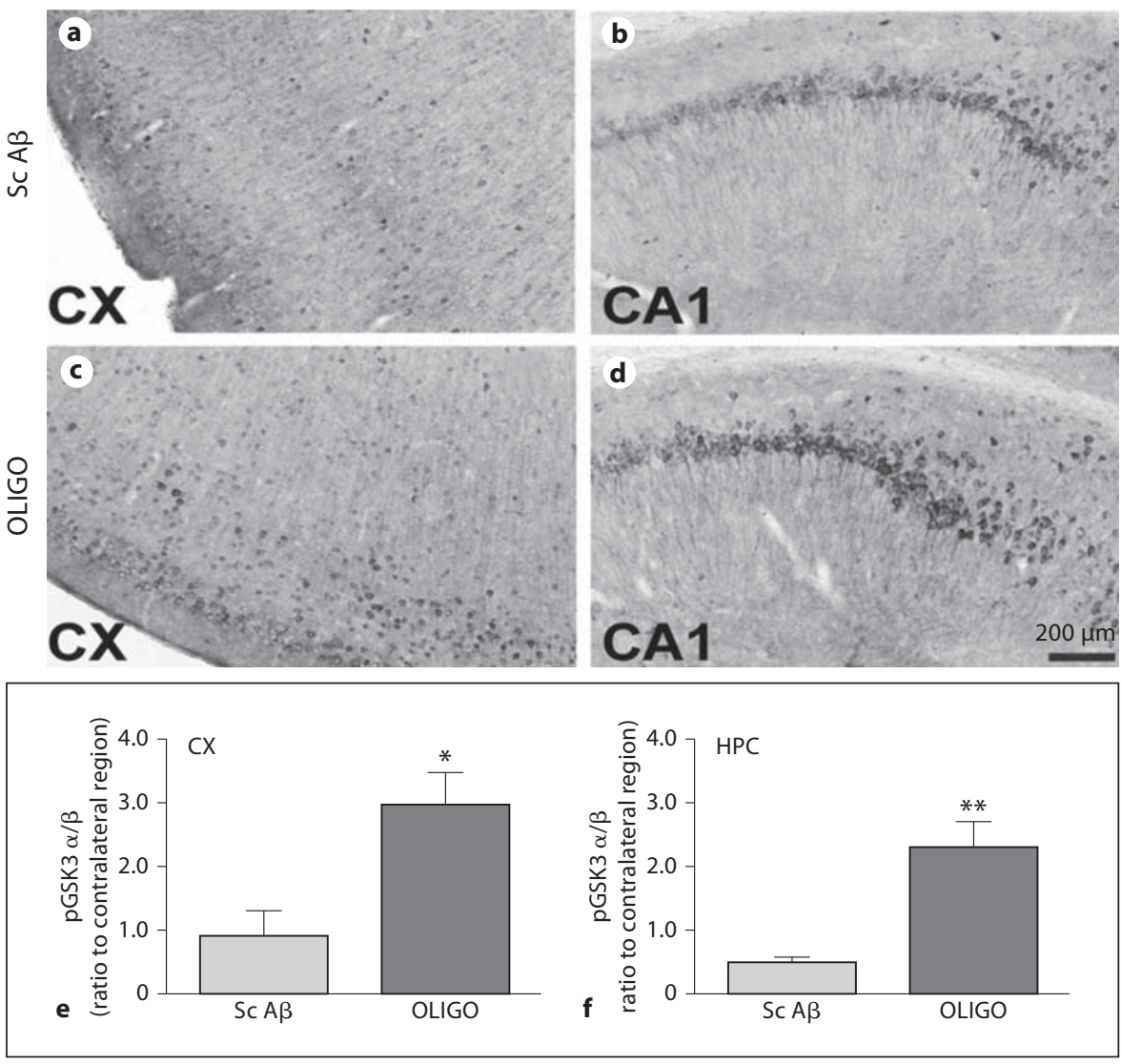

Hence, we concluded that oligomeric $A \beta_{1-42}$ was quickly cleared/degraded from the animal's brain. Thus, for protracted exposure of the brain to oligomeric $A \beta$, it would seem that a more sustained infusion would be required.

\section{Pathological p-Tau Was Not Altered by Acute}

\section{Administration of $A \beta_{1-42}$ Oligomers}

We subsequently performed immunohistochemical studies and image analyses to determine the levels of $\mathrm{p}$ tau in rTg4510 mice injected with oligomeric $A \beta_{1-42} \mathrm{com}$ pared with scramble $A \beta$ using murine littermates (fig. 3). Multiple p-tau epitopes [serine (S)202/threonine (T)205, S396 and S199/S202] as well as total tau were evaluated. The total tau antibody recognizes an epitope in the $\mathrm{N}$ terminus of human tau independent of phosphorylation. ptau staining in the anterior cortex (fig. 3a, b, e, f, i, j) and CA1 field of the hippocampus (fig. $3 c, d, g, h, k, l$ ) were readily detected by immunohistochemistry in rTg4510 mice. However, injection of oligomers did not alter p-tau levels in either region measured with any marker when compared to mice injected with the scrambled $A \beta$ peptide as a control for the injection procedure (fig. $3 q-s$ ).
Similar results were observed when comparing p-tau levels in injected versus uninjected hemispheres (data not shown). Acute injections of $A \beta_{1-42}$ oligomers did not produce striking changes in total tau staining (fig. $3 \mathrm{~m}-\mathrm{p}$ ), and this was reflected in image analysis measurements of immunostaining (fig. 3t).

\section{Acute $A \beta_{1-42}$ Oligomer Injection Was Associated with Alternations in GSK3 Activity}

Given the direct effect of GSK3 (glycogen synthase kinase-3) on tau pathology [28] we evaluated whether acute oligomer injections affect GSK3 activity in this model. Staining for pGSK3 $\alpha / \beta$ kinase at pY279/pY216 increased after acute injections of oligomers in the brain of $\mathrm{rTg} 4510$ mice compared with mice injected with scrambled $A \beta$ in the anterior cerebral cortex (fig. $4 \mathrm{a}, \mathrm{c}$ ) and the CA1 area of the hippocampus (fig. 4b, d). Quantification revealed that oligomeric $A \beta_{1-42}$ injection significantly induced pGSK $3 \alpha / \beta$ levels compare to scrambled $A \beta_{1-42}$ in both the frontal cortex (fig. $4 \mathrm{e},{ }^{*} \mathrm{p}<0.05$ ) and hippocampus (fig. 4 f, ${ }^{* *} \mathrm{p}<0.01$ ) of $\mathrm{rTg} 4510$ mice. 
Fig. 5. CD45 immunoreactivity was prominent in rTg4510 mouse brain and it did not alter following acute injections of oligomers (OLIGO). Micrographs represent CD45 immunoreactivity in the frontal cortex (CX) and hippocampus (HPC) of rTg4510 mice following injection of scrambled (Sc) A $\beta(\mathbf{a}, \mathbf{b} ; \mathbf{n}=5)$ or OLIGO (c, d; $\mathrm{n}=5$ ). Staining intensity was analyzed as percent of stained area for each region and graphed as ratio of the ipsilateral to the contralateral side $(\mathbf{e}, \mathbf{f})$.
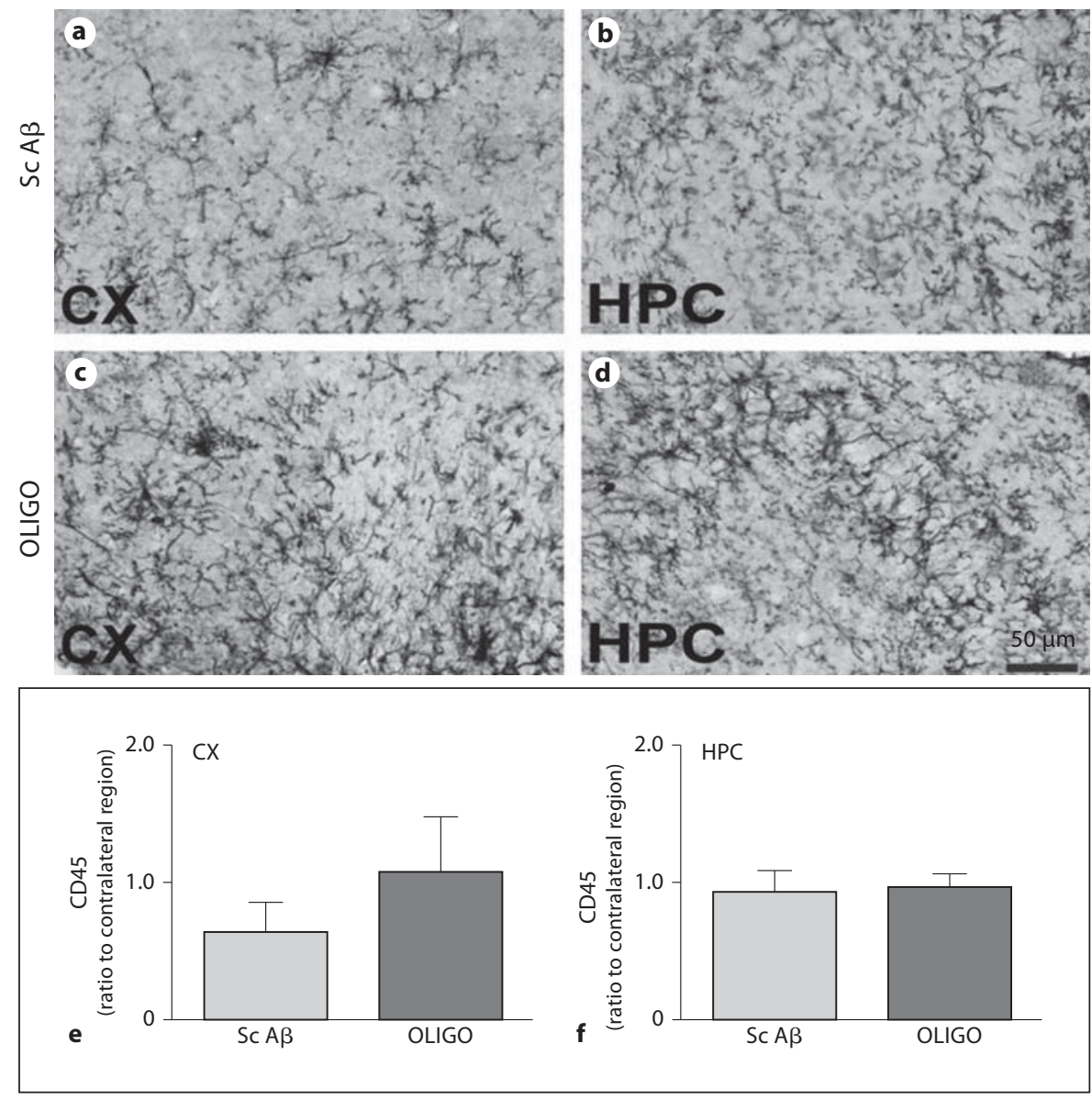

Acute Injection of $A \beta_{1-42}$ Oligomers Did Not

Exacerbate the Microgliosis Present in rTg4510 Mice

Acute injections of oligomeric $A \beta$ did not modify the activation state of microglia, assessed by either CD45 (fig. 5) or CD68 immunostaining (fig. 6). Although the data presented here compare the hemispheres injected with oligomeric $A \beta$ and scrambled $A \beta$ peptide, similar findings were true in comparisons between the oligomeric A $\beta$-injected hemisphere and the contralateral hemisphere (not shown).

Chronic Infusion of $A \beta_{1-42}$ Oligomers in rTg4510 Mice Enhances Phosphorylation of Tau

Although acute administration of $A \beta$ oligomers had no impact on p-tau, it is less clear what the impact of longer exposure would be. We infused a solution containing $100 \mu \mathrm{M} \mathrm{A} \beta_{1-42}$ oligomers or saline (as a surgical control) into the right hippocampus of 3-month-old rTg4510 mice for 28 days using osmotic minipumps and indwelling intracranial cannulae. We also infused oligomeric $A \beta$ into ntg animals lacking human tau. We then collected tissue 60 days after pump implantation, to ascertain if there were any enduring effects of the $A \beta$ oligomers on histopathology in the rTg4510 mice.

We evaluated several p-tau epitopes (table 1) in the CA1 field of the hippocampus and entorhinal cortex. S199/202 p-tau was localized to neuronal cell bodies of the pyramidal cells of CA1 (fig. 7c, e) as well as to neurons in the entorhinal cortex (fig. 7d, f) in rTg4510 mice. Infusion of oligomers into the hippocampus increased p-tau S199/202 in this region compared to saline-treated rTg4510 animals (fig 7c, e, g; p < 0.01). A trend toward increased S199/202 p-tau level was observed in the entorhinal cortex, but did not reach significance (fig. $7 d$, f, h). Injection of oligomers in ntg mice did not result in phosphorylation of S199/202 epitopes of endogenous mouse tau (fig. 7a, b; not quantified due to signal absence).

Similar results were observed for p-tau S202/T205 staining. In saline-treated rTg4510 mice, p-tau S202/ 
Fig. 6. CD68 immunoreactivity present in the transgenic mice did not alter following acute oligomer (OLIGO) injections. Micrographs representing CD68 immunoreactivity in $\mathrm{rTg} 4510$ mouse regions of the frontal cortex (CX) and hippocampus (HPC) injected with scrambled (Sc) A $\beta$ (a, b; $\mathrm{n}=5)$, or OLIGO (c, d; $\mathrm{n}=5$ ). Staining intensity was analyzed as percent of stained area for each region and expressed as ratio to the contralateral side $(\mathbf{e}, \mathbf{f})$.
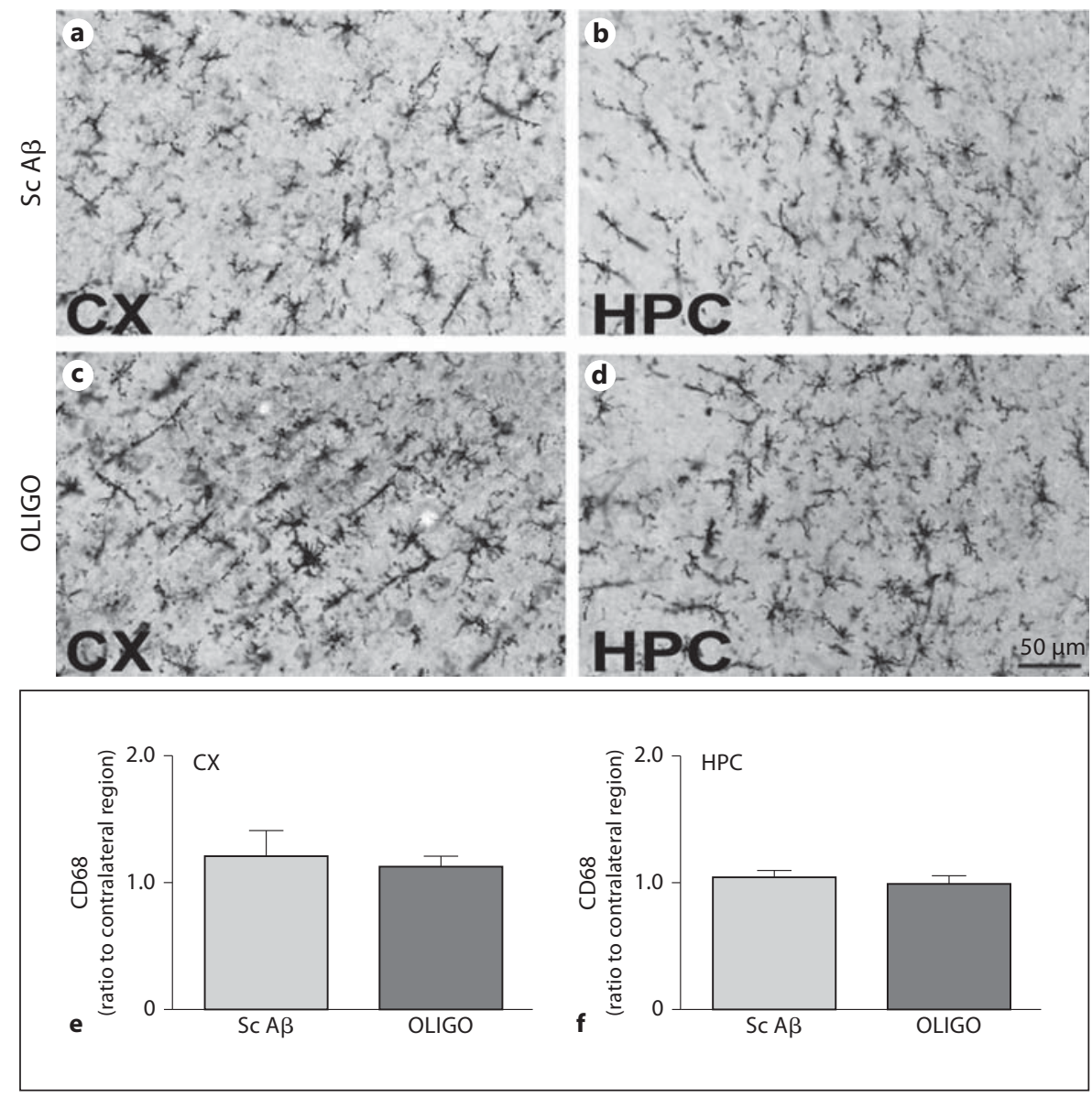

T205 was localized to neuronal soma of pyramidal and cortical neurons (inset, fig. 8a, c). Interestingly, p-tau at the S202/T205 epitope in oligomer-treated mice displayed somatodendritic localization in pyramidal CA1 neurons (inset, fig. 8c). Oligomers dramatically increased the levels of p-tau S202/T205 in the right hippocampus of rTg 4510 mice compared to the saline-treated group (fig. 8e; $p<0.01$ ). In contrast, infusion of oligomeric $A \beta$ did not significantly induce $p$-tau S202/T205 in the entorhinal cortex areas compared to saline-infused animals (fig. 8f).

Based on the evidence of the involvement of tau phosphorylated at S396 in modifying microtubule binding and promoting neuronal degeneration [29], we evaluated the pS396 levels as an indicator of tau pathology. Significantly increased levels of pS396 tau were observed in the right hippocampus of oligomer- versus saline-treated rTg4510 groups (fig. 9c, e, g; $p<0.05$ ). Furthermore, $A \beta$ oligomer infusion did not induce significant changes in p-tau levels in the entorhinal cortex (fig. 9d, f, h).
We investigated total tau expression using an antibody which recognizes an $\mathrm{N}$-terminal domain epitope of human tau irrespective of the phosphorylation status (fig. 10). We were unable to detect tau in the ntg mice with this antibody (fig. 10a, b). Total tau was localized in the neuron cell body and oligomer delivery did not significantly affect total tau levels in rTg4510 mice compared to the saline-treated cohort (fig. 10c-h). Similarly, staining for another paired helical filament-tau epitope, pS356, demonstrated $\mathrm{p}$-tau somatic localization in neurons, but no significant effect of oligomers was observed between groups (data not shown).

\section{GSK 3 Is Elevated in the rTg4510 Model and in \\ Response to $A \beta_{1-42}$ Oligomers}

In rTg4510 mice, $A \beta$ oligomer infusion augmented pGSK3 immunoreactivity in the hippocampus compared to the saline-treated group (fig. 11a, c, e, g; p < 0.05). In spite of increased levels of pGSK3 in rTg4510 mice compared to the ntg group in the entorhinal cortex (fig. 11b, d), the dif- 
Fig. 7. Chronic infusion of oligomers (OLI$\mathrm{GO}$ ) increased immunostaining for S199/202 p-tau. S199/202 p-tau immunoreactivity in the CA1 region of the hippocampus (HPC, CA1; depicted images are taken $700 \mu \mathrm{m}$ from the center of the cannula; c, e) or entorhinal cortex (EC; 1,600 $\mu \mathrm{m}$ from the center of the cannula; d, f) of rTg4510 mice infused with saline (c, d) or OLIGO $(\mathbf{e}, \mathbf{f})$ into the right HPC are shown in all figures from this point unless stated otherwise. Ntg mice infused with OLIGO preparations are used as controls (a, b). Staining intensity was analyzed as percent of stained area for each region $(\mathbf{g}$, h). Student's t test: ${ }^{* *} \mathrm{p}<0.01, \mathrm{n}=6$.
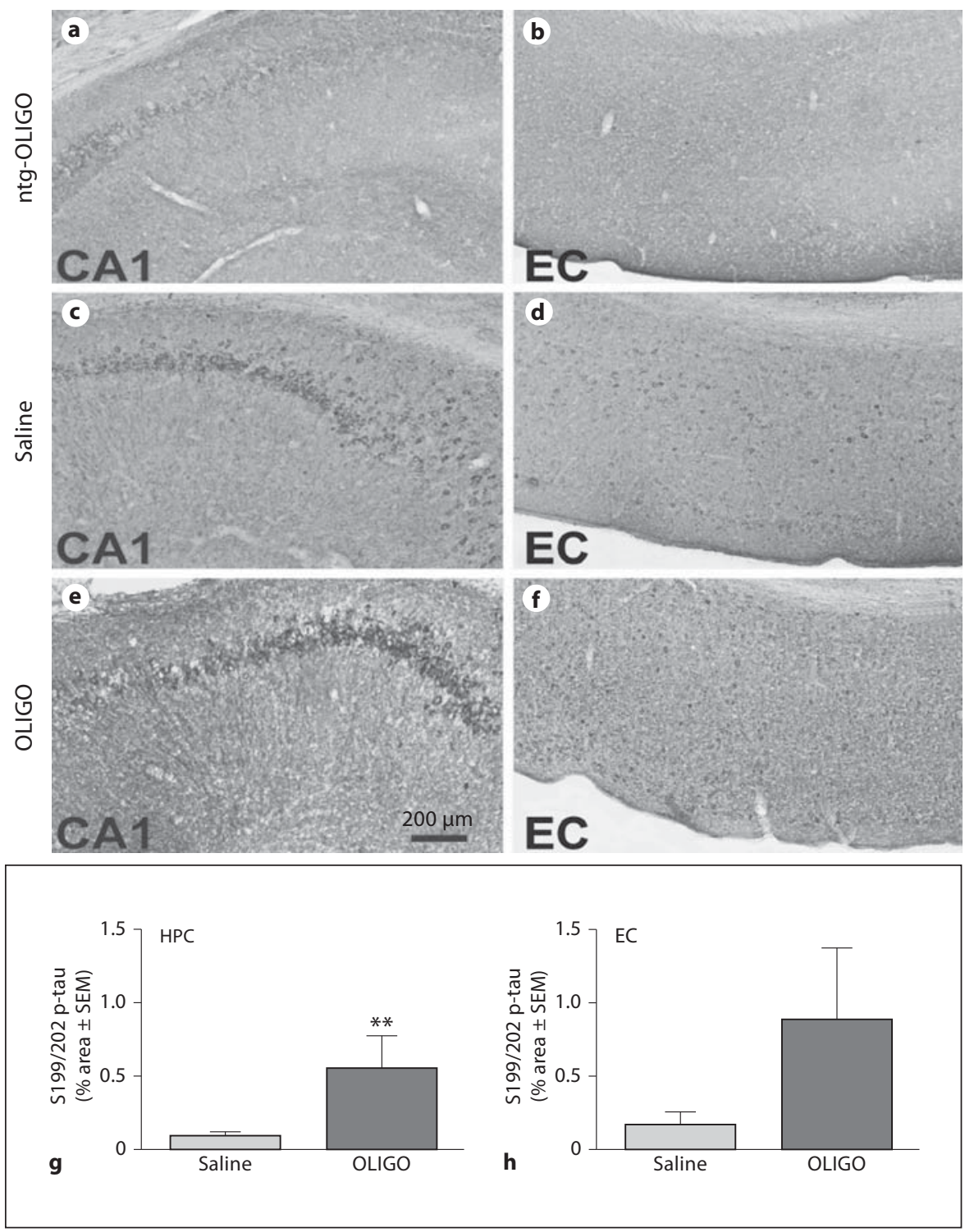

ference between saline- and oligomer-injected $\operatorname{rTg} 4510$ mice did not achieve statistical significance (note the neuronal localization of pGSK/activated GSK3 in figure 11).

Finally, we looked at the relationship between activated GSK3 and p-tau in rTg4510 mice. We used immunofluorescence to co-localize S202/T205 p-tau (fig. 12a, e) and pGSK3 (fig. 12b, e) in the tissue from oligomer-injected rTg4510 mice. Immunofluorescent staining revealed a considerable degree of co-localization of GSK3 with AT8 p-tau in the CA1 (fig. 12a-c) and entorhinal cortex (fig. 12d-f). Both markers appeared to be located to the perinuclear area, as shown by the merged images with nuclear DAPI staining (fig. 12c, f).

\section{CD68-Positive Microglia but Not CD45 Microglia} following Chronic $A \beta_{1-42}$ Oligomer Infusion

Intracerebral injection of $A \beta$ aggregates and derived oligomers has been linked with increased microgliosis [24]. We stained for CD45 and CD68 to monitor microglial activation. Consistent with our group's previous observations [30], at 5 months of age, the presence of tau pathology in rTg 4510 mice is accompanied by increased CD45 immunoreactivity compared with ntg mice (fig. 13a, b). After oligomer infusion, the microglial morphology showed a trend towards a more activated phenotype, with enlarged somata and thickened processes (fig. 13e) compared to saline-injected mice (fig. 13c). 
Fig. 8. Infusion of oligomers (OLIGO) increased immunostaining for S202/T205 ptau. Micrographs of S202/T205 p-tau immunoreactivity in the CA1 (hippocampus, HPC) and entorhinal cortex (EC) of rTg4510 mice infused with saline $(\mathbf{a}, \mathbf{b})$ or OLIGO $(\mathbf{c}, \mathbf{d})$ are presented. Insets $(\mathbf{a}, \mathbf{c})$ represent higher magnifications of $\mathrm{p}$-tau localization in the cell body and dendrites of neurons. Staining intensity was anaregion $(\mathbf{e}, \mathbf{f})$. Student's t test: ${ }^{* *} \mathrm{p}<0.01$, $\mathrm{n}=6$. lyzed as percent of stained area for each
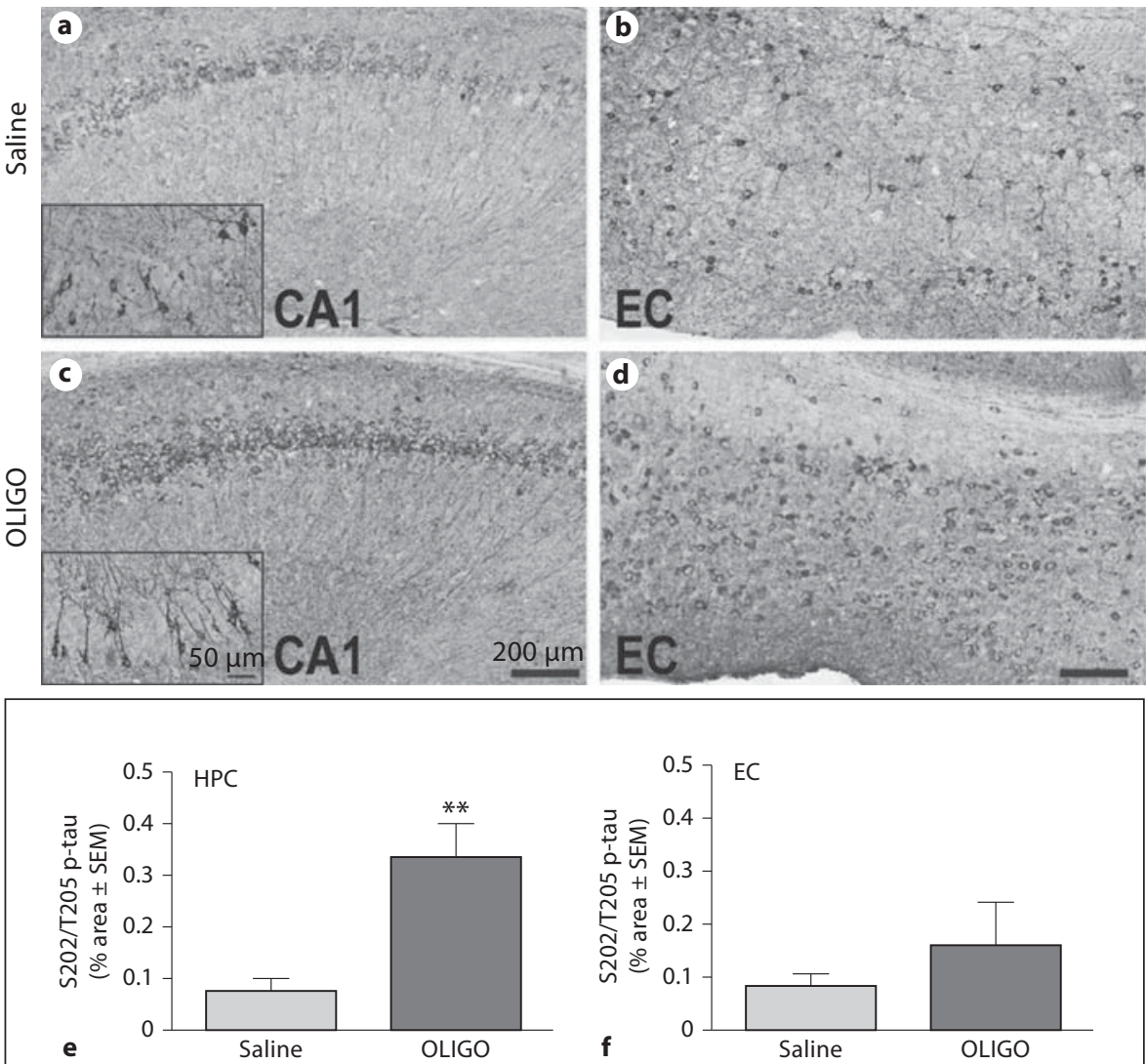

However, statistically significant differences in the immunostained area were observed in the hippocampus in comparison to the ntg mice (fig. 13a, g). This suggests that the CD45 expression of activated microglia in $\mathrm{rTg} 4510$ mice is tau pathology-related and independent of oligomer administration. These results were in agreement with the acute effects of oligomers on CD45-activated microglia (fig. 5).

We did not observe activation of CD68 phagocytic microglia in ntg oligomer-infused animals (fig. 14a, b). Moreover, rTg4510 infused with saline displayed modest amounts of CD68 immunoreactivity (fig. 14c, d). Chronic infusion of oligomers induced activation of CD68 phagocytic microglia (fig. 14e, f). Image analysis showed that $\mathrm{A} \beta$ oligomer infusion significantly increased CD68 expression in the hippocampus (fig. 14g; $\mathrm{p}<0.05$ ) and entorhinal cortex (fig. 14h; p < 0.05) compared to both ntg and rTg4510 saline-infused animals. We also examined another microglial marker, CD11b, and an astrocyte marker, glial fibrillary acidic protein (GFAP), by immunofluorescence. We observed an increase in
$\mathrm{CD} 11 \mathrm{~b}+$ microglia in the hippocampus of rTg45140 animals chronically infused with oligomers (red, online supplementary fig. 1C; for all online supplementary material, see www.karger.com/doi/10.1159/000337230) compared to the saline controls (online suppl. fig. 1A), with less effect in the entorhinal cortex (online suppl. fig. $1 \mathrm{~B}$ vs. D). However, no changes in astrocytosis were observed as shown by GFAP immunohistochemistry analysis (green, online suppl. fig $1 \mathrm{E}-\mathrm{H}$ ). Merging of the CD11b and GFAP images indicated little overlap of these two distinct populations of cells (microglia and astrocytes).

\section{Stability of Oligomeric A $\beta$ within the Minipump}

To monitor structural changes in the injected sample, the same oligomer preparation used for the intracranial injections was loaded into an osmotic pump kept under physiological conditions (isotonic buffer at $37^{\circ} \mathrm{C}$ ), and samples were collected after 1,10 or 27 days of incubation. Interestingly, after 1 day of incubation within the pump, the monomeric species decreased precipitously and a clus- 

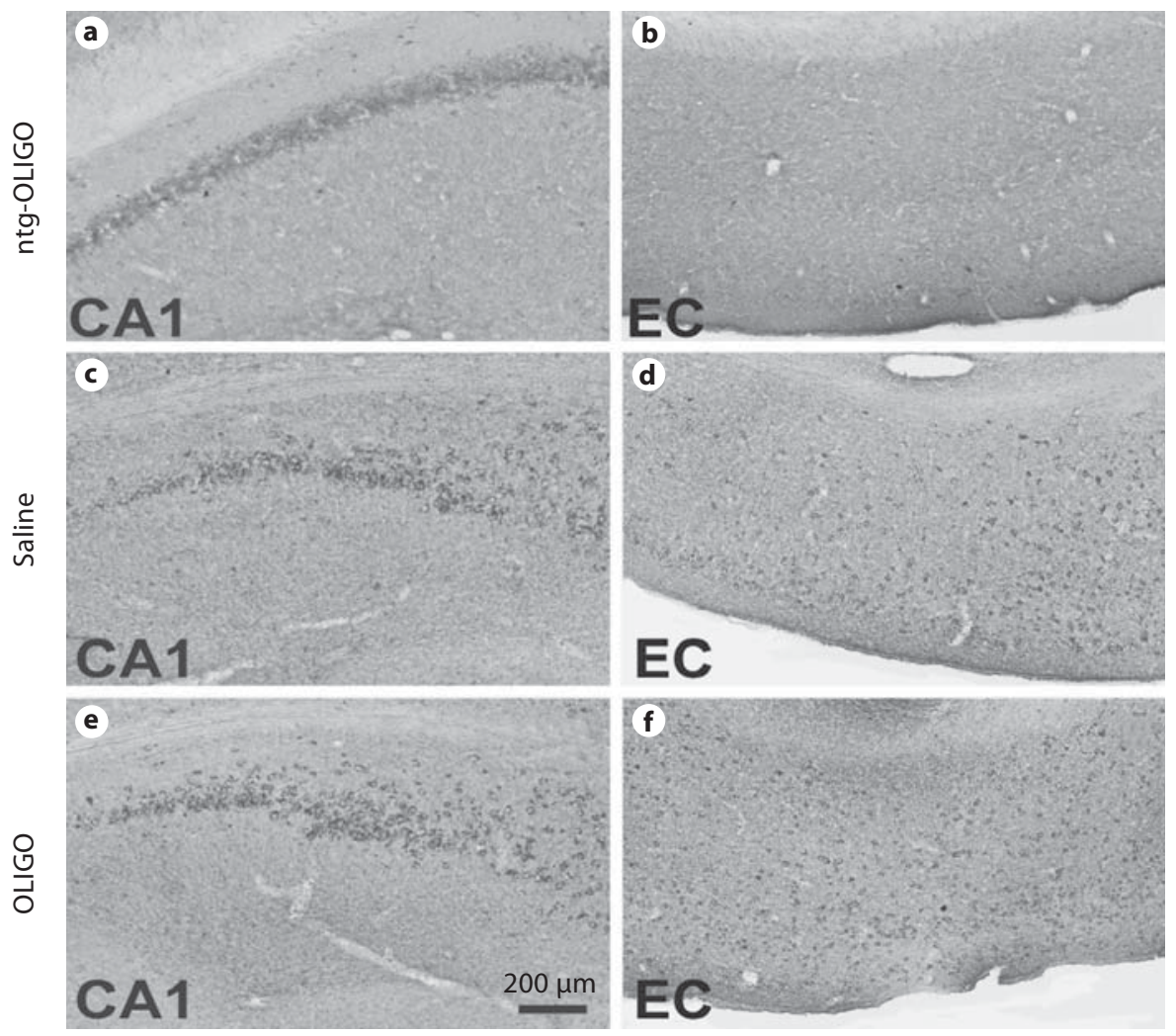

Fig. 9. Infusion of oligomers (OLIGO) increased S396 p-tau levels. S396 p-tau immunoreactivity in the CA1 (hippocampus, $\mathrm{HPC} ; \mathbf{a}, \mathbf{c}, \mathbf{e})$ and entorhinal cortex (EC; b, $\mathbf{d}, \mathbf{f})$ of ntg mice infused with $\operatorname{OLIGO}(\mathbf{a}, \mathbf{b})$ and $\mathrm{rTg} 4510$ mice infused with saline (c, d) or $\operatorname{OLIGO}(\mathbf{e}, \mathbf{f})$. Staining intensity in rTg4510 mice was analyzed as percent of stained area for each region $(\mathbf{g}, \mathbf{h})$. Student's t test: ${ }^{*} \mathrm{p}<0.05, \mathrm{n}=6$.

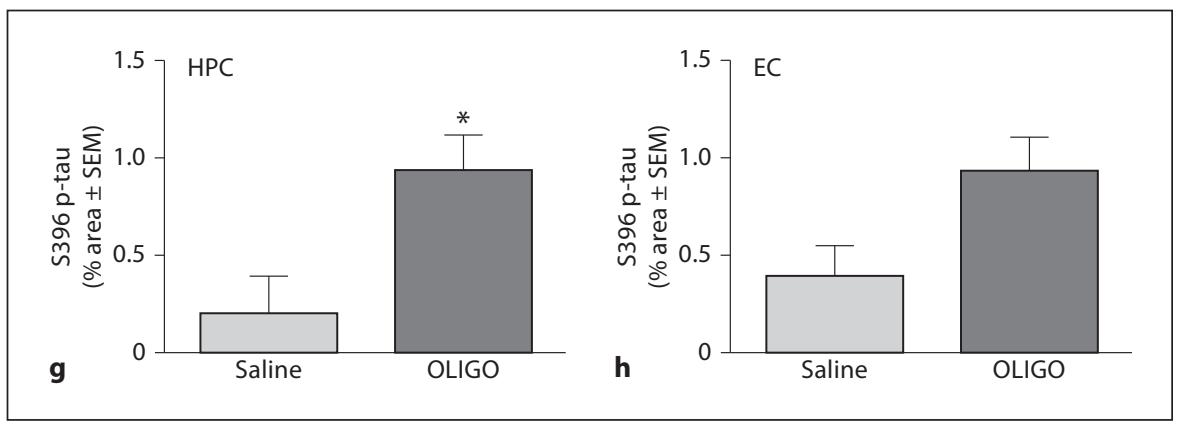

ter of LMW material appeared, primarily migrating at a molecular weight consistent with trimers (online suppl. fig. 2). HMW oligomers (38- to $180-\mathrm{kDa}$ bands) were present at all the sampling times, but decreased during the 27day incubation period. Large aggregates were also visible at the top of the gel and continued to be present up to 10 days (data not shown). Western blot data suggested that oligomers kept ex vivo but inside the osmotic pump contain a mixture of oligomer species. On day 27, the solution exiting the pump contained little $A \beta$ protein. It is possible that this hydrophobic protein adhered to the inside of the osmotic pump or aggregated and precipitated in a manner that prevented additional release from the pump.

\section{Discussion}

Several lines of evidence suggest that $A \beta$ pathology precedes and can potentiate tau pathology. First, it is generally regarded that the initial pathology to develop in $\mathrm{AD}$ patients is $\mathrm{A} \beta$ deposition, and this is followed by tau pathology with several years delay [31, but see ref. 32 for a different perspective]. Second, mutations in tau do not recapitulate the pathological or behavioral correlates of AD [33], while mutations affecting the APP or its processing do reproduce most features associated with sporadic AD [34]. Moreover, in AD the brain regions developing tau pathology are, at least sequentially, distinct from those brain regions affected by other 

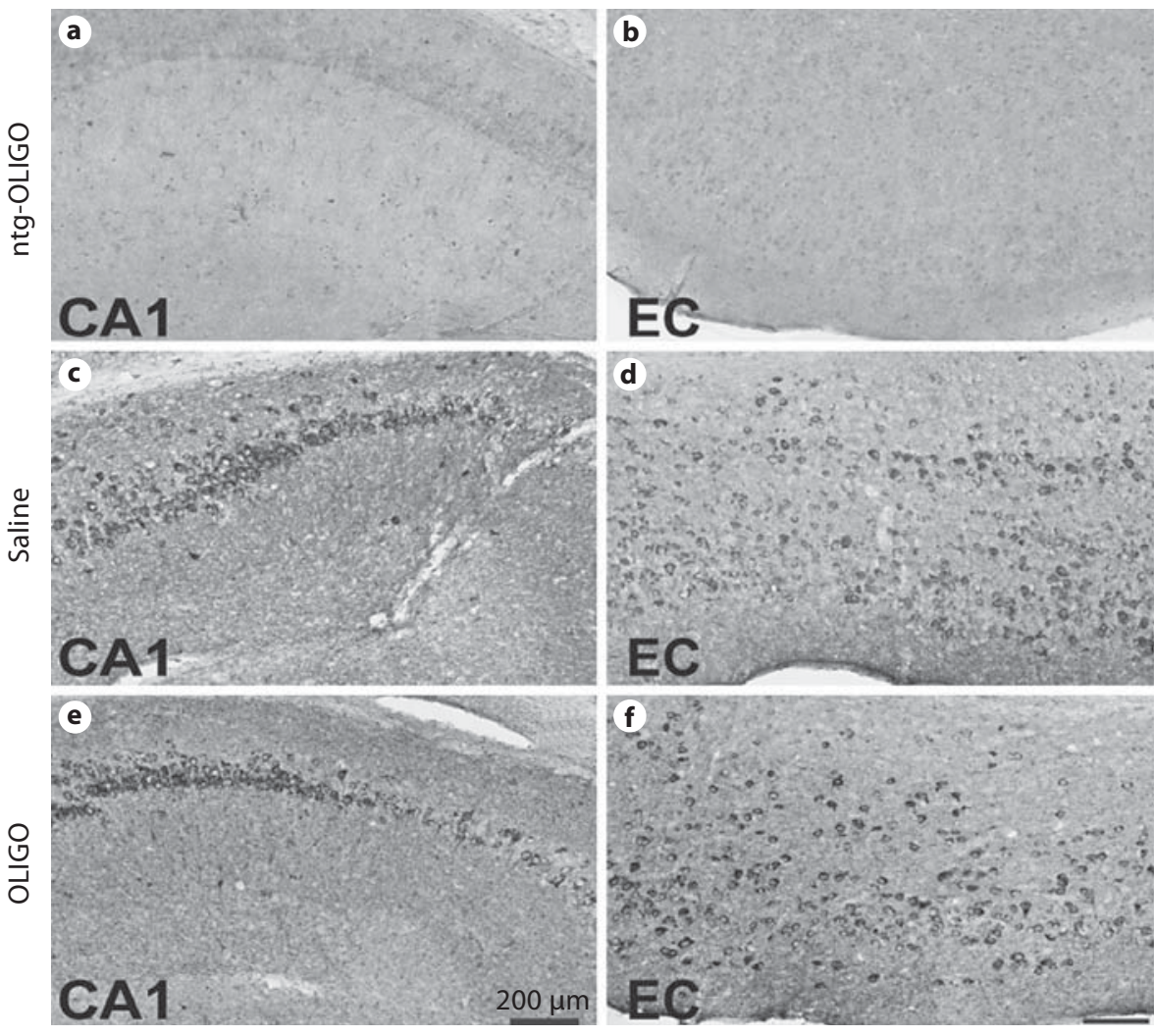

Fig. 10. Total tau levels remain unchanged following chronic infusion of oligomers (OLIGO). Total tau immunoreactivity in CA1 (hippocampus, HPC) and entorhinal cortex (EC) of rTg4510 mice infused with saline $(\mathbf{c}, \mathbf{d})$ or OLIGO $(\mathbf{e}, \mathbf{f})$ is shown. Endogenous tau was not detectable in ntg mice (a, b). Staining intensity was measured as percent of stained area for each region $(\mathbf{g}, \mathbf{h})$, but was unaffected by treatment. Student's t test: $\mathrm{n}=6$.

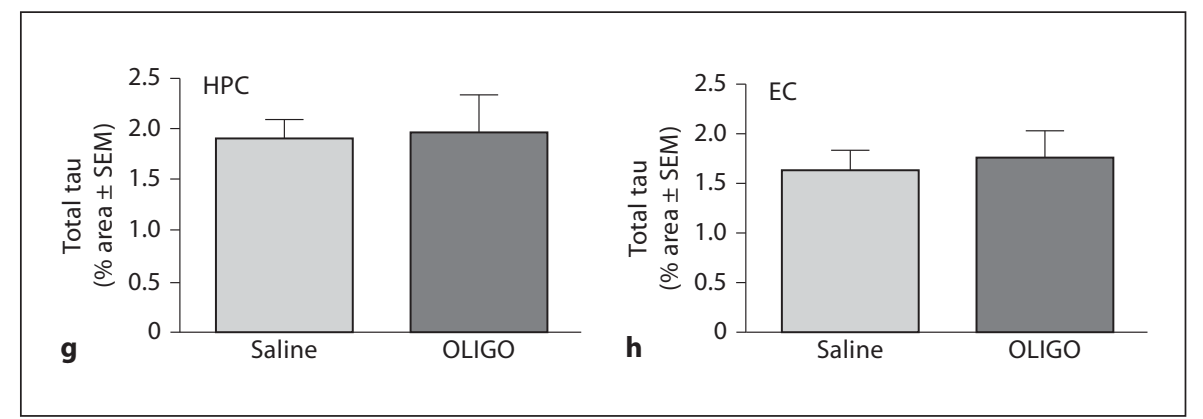

tauopathies. This leads to the suggestion that one consequence of amyloid deposition in $\mathrm{AD}$ may be to precipitate tau pathology.

Similar evidence of $A \beta$-induced exacerbation of tau pathology is accumulating in studies in animal models. Geula et al. [35] observed that intracranial injections of fibrillar but not soluble $A \beta$ could initiate tau pathology in aged marmosets (this was prior to attempts to isolate oligomeric forms of $A \beta$ ). Forebrain tau pathology has been shown to be enhanced by $A \beta$ administration in tau transgenic mouse models $[10,27]$. More recently, injection of aged APP brain extract into the brain of young B6/ P301L mice was also shown to increase tau pathology [9]. Immunotherapeutic approaches or genetic modifications which reduce $A \beta$ accumulation slow the development of tau pathology in models exhibiting both pathologies [36, 37]. Furthermore, studies suggest a postsynaptic role for tau in conferring $A \beta$ effects on cognitive function [18] and dendritic toxicity $[20,38]$.

In this experiment, we examined the impact of acute versus chronic administration of $A \beta_{1-42}$ oligomers in tau phosphorylation. First, we investigated the composition of the $A \beta_{1-42}$ oligomers that were used for in vivo infusion. The $A \beta$ oligomer sample initially contained a mixture of LMW forms with stable, globular structures; $A \beta$ oligomers are cleared and/or degraded from brain parenchyma within days (fig. 2), consistent with earlier work using nonfibrillar forms of $A \beta[39,40]$. Study of the ma- 

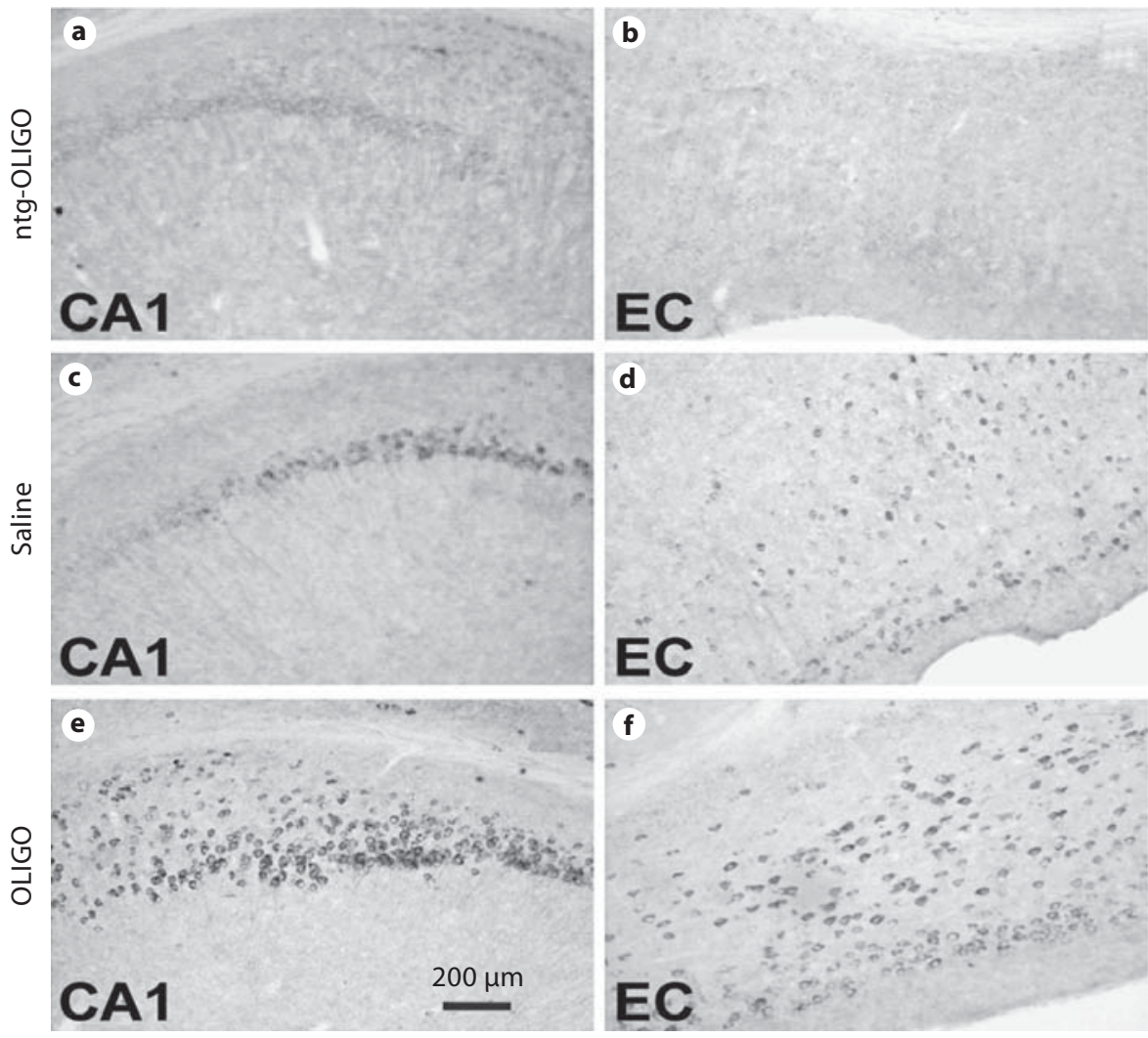

Fig. 11. Activation of GSK3 increased following chronic infusion. pGSK $3 \alpha / \beta$ immunoreactivity in the CA1 and entorhinal cortex (EC) of $\operatorname{rTg} 4510$ or ntg mice $(\mathbf{a}, \mathbf{b})$ following infusion of saline $(\mathbf{c}, \mathbf{d})$ or OLI$\mathrm{GO}(\mathbf{e}, \mathbf{f})$ into the right hippocampus (HPC). Staining intensity was analyzed as percent of stained area for each region of rTg4510 (g, h). Student's t-test: * $\mathrm{p}<0.05$, $\mathrm{n}=6$.

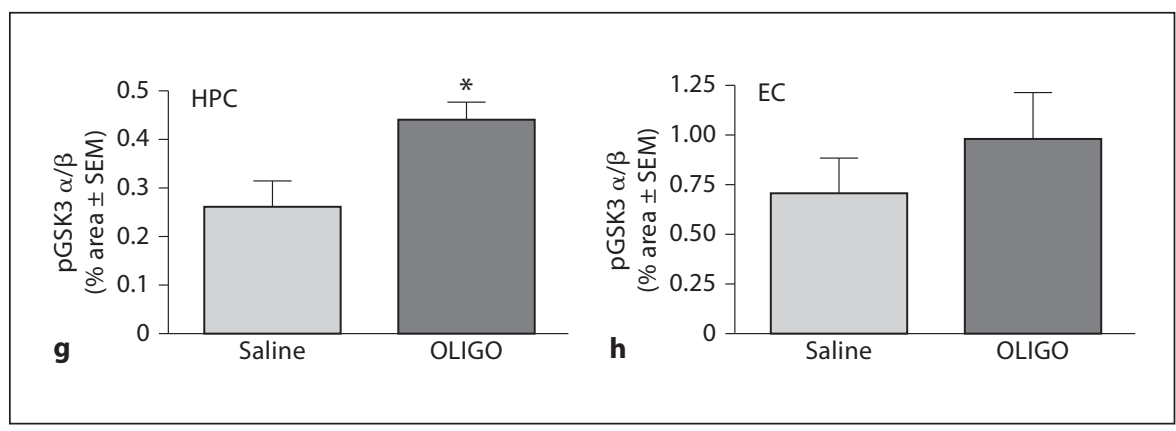

terial exiting from the pumps revealed that larger aggregates predominated if the material was incubated at $37^{\circ} \mathrm{C}$ in physiological buffer inside the osmotic minipump. This observation is in agreement with data published previously showing metastable structures of $A \beta$ with increased temperature [21]. This led to either precipitation of the aggregates or adsorption of the material onto the lining of the pump chamber or polyethylene tubing. In either case, these results indicate that the infusion of $A \beta$ oligomers was largely complete by 10 days after pump implantation. Without the inclusion of this in vitro control condition in the study, we would not have discovered this early termination of $A \beta$ infusion.
For these experiments, we selected the age of 5 months in the rTG4510 model because this is a time when some tau pathology is evident but not maximal $[8,41]$. Acute injections of $A \beta$ oligomers did not alter the $p$-tau levels at any of the epitopes investigated in vivo at the 3-day postinjection interval (fig. 3). We selected this interval as one in which we have previously observed effects of intracranially administered agents [42-45]. It is unclear whether the lack of effect indicates that none had yet developed, or that the clearance of $A \beta$ led to rapid reversal of $p$-tau changes that might have occurred. This is in contrast to the recent evidence of an acute effect of $A \beta$ oligomers on tau phosphorylation in cultured hippocampal neurons [46]. Whether this represents true differences between in 
Fig. 12. p-tau co-localized with activated GSK3 in rTg4510 mouse brain. p-Tau at S202/T205 (AT8; green in the online version) is co-localized with pGSK $3 \alpha / \beta$ (red in the online version) in the neuronal cell bodies of CA1 $(\mathbf{a}-\mathbf{c})$ and entorhinal cortex (EC; d-f) in rTg4510 mice infused with OLIGO. DAPI was used to stain nuclei (blue in the online version).

Fig. 13. CD45 immunoreactivity is prominent in rTg4510 mouse brain and independent of oligomer (OLIGO) infusion. Micrographs represent CD45 immunoreactivity in the CA1 region of the hippocampus (HPC) and entorhinal cortex (EC) of OLIGO-infused ntg mice (a, b), and rTg4510 mice following saline $(\mathbf{c}, \mathbf{d})$ or OLIGO infusion $(\mathbf{e}, \mathbf{f})$. Staining intensity was analyzed as percent of stained area for each region $(\mathbf{g}, \mathbf{h})$. Statistical comparisons by one-way ANOVA and Fisher's PLSD were performed using StatView software. ${ }^{*} \mathrm{p}<$ $0.05, \mathrm{n}=6$.

Amyloid Oligomers Exacerbate Tau Pathology
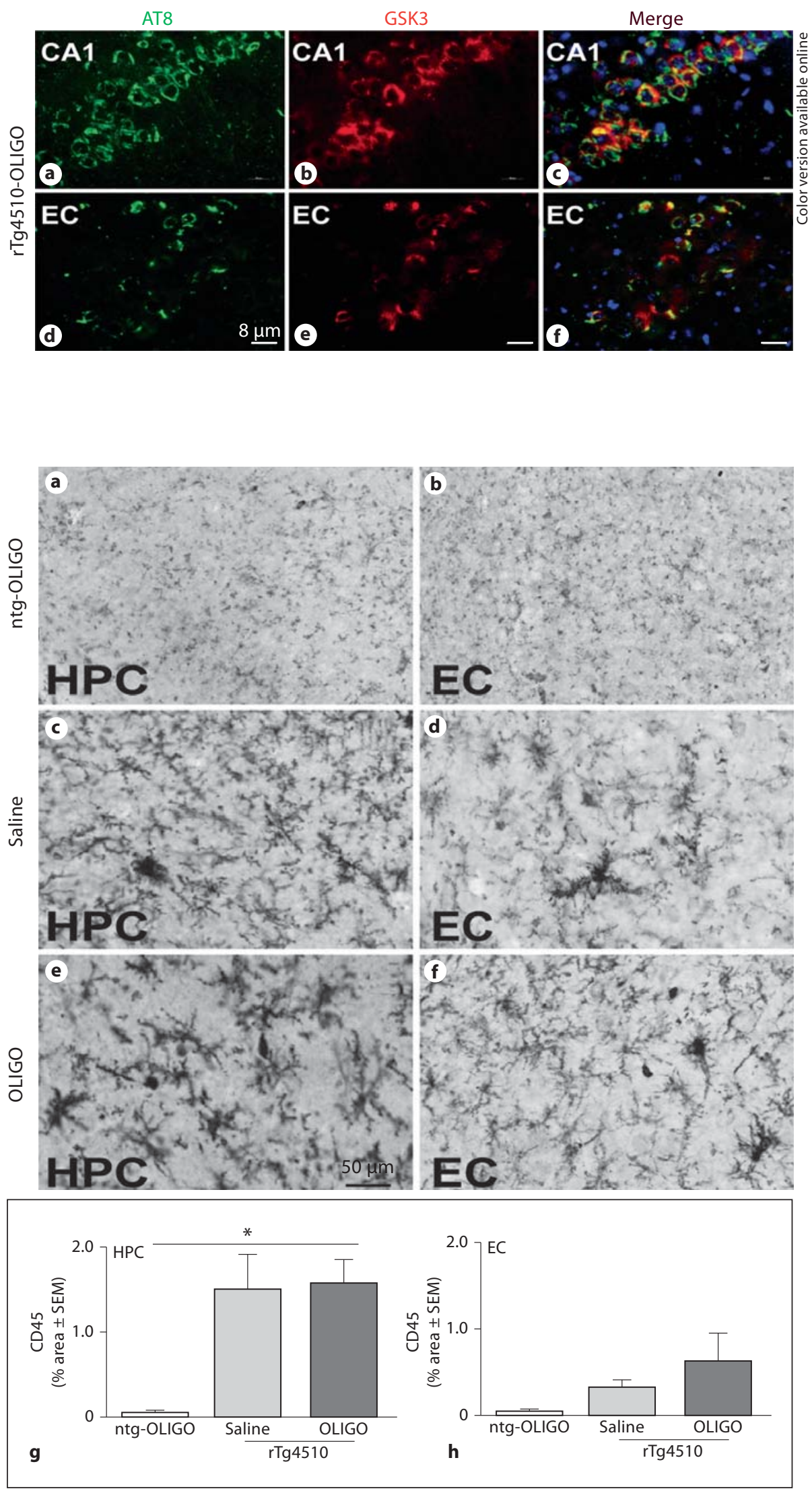
Fig. 14. CD68 immunoreactivity is increased in oligomer (OLIGO)-infused rTg4510 mice. Micrographs represent CD68 immunoreactivity in the CA1 region of the hippocampus (HPC) and entorhinal cortex (EC) of ntg mice infused with OLIGO (a, b), and rTg4510 mice following saline $(\mathbf{c}, \mathbf{d})$ or OLIGO infusion (e, f). Staining intensity was analyzed as percent of stained area for each region $(\mathbf{g}, \mathbf{h})$. CD68 immunostaining was elevated in OLIGO-treated rTg4510 mice compared with either ntg mice treated with OLIGO (ntg-OLIGO) or rTg4510 mice treated with saline. Statistical comparisons by one-way ANOVA and Fisher's PLSD were performed using StatView software. ${ }^{*} \mathrm{p}<$ $0.05, \mathrm{n}=6$.
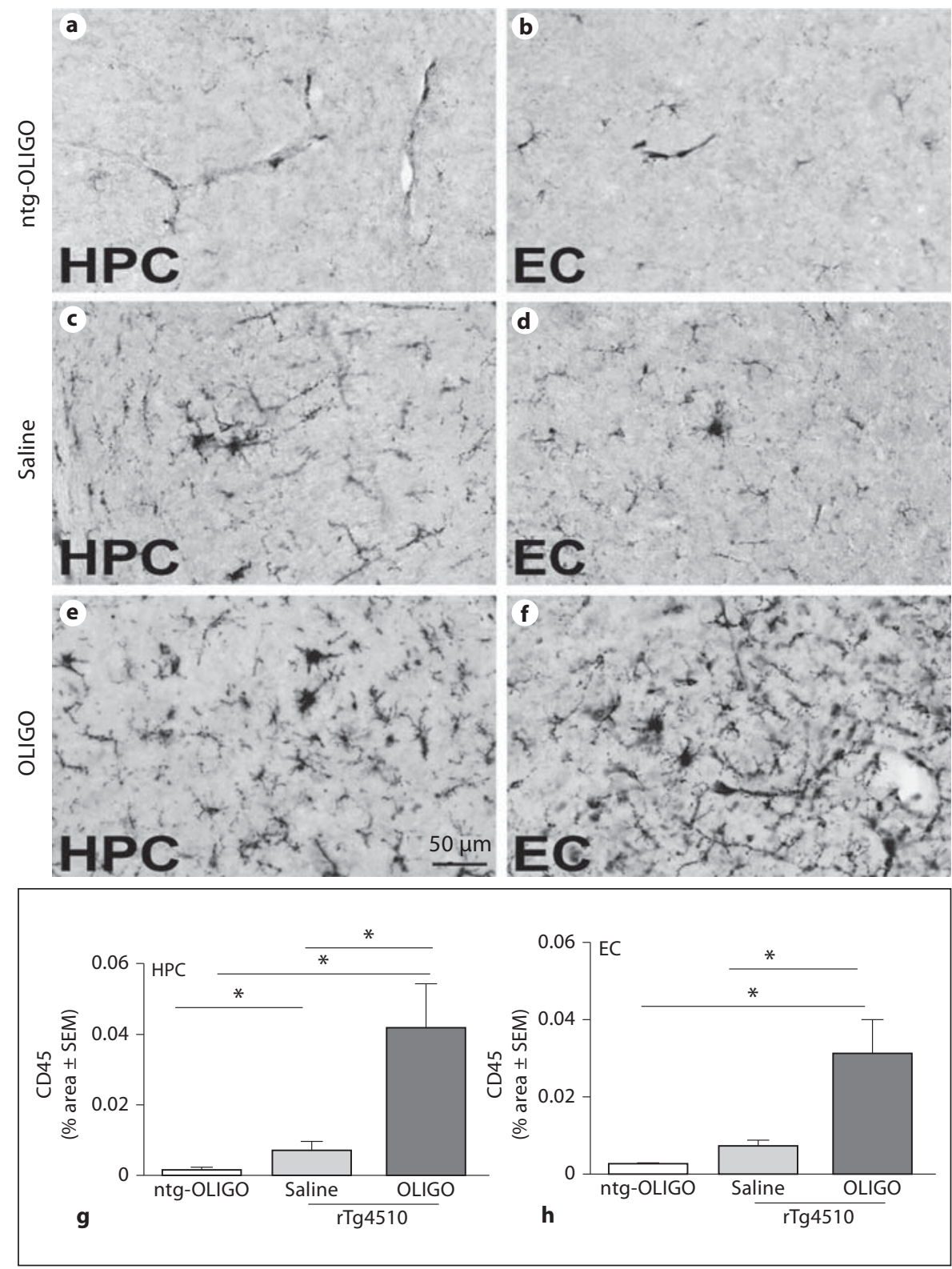

vitro and in vivo models, or is a product of the reduced magnitude of effect in vivo is not clear at this stage. However, a key observation in the mice injected acutely with $A \beta$ oligomers was a significant increase in the active form of GSK3, a kinase capable of phosphorylating multiple sites on tau $[47,48]$.

Unlike the acute treatment, chronic infusion of $A \beta$ oligomers increased $\mathrm{p}$-tau in vivo. Staining for p-tau using several antibodies (pS199/S202, pS202/T205 and pS396) was elevated 3- to 4-fold in the injected hippocampus (fig. 7, 9) compared to the saline-treated rTg4510 group. Although the adjacent entorhinal cortex indicated a trend towards an increase, this was not statistically significant. No differences were observed contralateral to the side of injection. The pS396 epitope is suggested to be involved in microtubule destabilization and paired helical filament formation in AD brain [29]. However, not all forms of tau were elevated. Total tau and the pS356-specific antibody were unaffected by the $A \beta$ oligomer treatment. It is important to note that these effects are enduring, as the infusion of $A \beta$ oligomers probably ceased 6 weeks prior to tissue collection. This observation implies 
that even transient stimulation of tau pathology can have long-lasting impact on the rate of tauopathy development, and at some stage these changes are irreversible (consistent with suppression of the transgene with doxycycline [8]).

Perhaps most intriguing was the persistence of the GSK3 activation induced by the injection of $A \beta$ oligomers into the hippocampus. As in the acute study, the phosphorylation and activation of this enzyme persists after the injected $A \beta$ has been cleared from the brain (fig. 11). Moreover, there is a large degree of overlap between cells expressing elevated pS202/T205 and GSK3, implying that this elevated kinase expression may be responsible for the increased p-tau. During both brain development and in neurodegenerative diseases, activated GSK3 is associated with hyperphosphorylated tau and the two markers are co-localized within neurons [49]. Consistent with our findings, in vitro [50] and in vivo studies [51] report $A \beta$ oligomer-induced tau pathology through active GSK $3 \alpha / \beta$. To our knowledge, this is the first report that the activation of GSK $3 \alpha / \beta$ kinase by $A \beta$ oligomers persists beyond the period of direct exposure to the $A \beta$. This may be one mechanism by which shortterm elevations in $A \beta$, e.g. following head injury [52], can increase the risk for subsequent tauopathy.

We previously demonstrated the role of potent inflammatory stimuli, e.g. lipopolysaccharides, on exacerbating tau pathology [30]. Furthermore, we reported that increases in several markers of microglial activation were dependent on age and pathological tau accumulation in rTg4510 mice [30]. Our data show two important findings: (1) rTg4510 mice exhibit microglial activation (measured with CD68) compared to ntg animals independent of acute exposure to the oligomers and (2) chronic infusion of $A \beta_{1-42}$ oligomer exacerbates microglial activation. A straightforward interpretation of these data is that the p-tau pathology resulted in microglial overexpression of CD68. Interestingly, our data demonstrate that CD45immunoreactive microglia were not affected by either acute or chronic administration of oligomers in the brain. This is quite distinct from observations in mice with amyloid deposits [25]. Given the suggestion that CD45-high immune-positive cells are derived from infiltrating monocytes [53], this would suggest that tau pathology does not lead to significant recruitment of blood-derived cells.

In conclusion, we demonstrate evidence for the involvement of $A \beta$-derived oligomers in modifying the level of hyperphosphorylated tau. The neuropathological symptoms of $\mathrm{AD}$ are multifactorial and many kinases and molecular mechanisms contribute to the disease; however, we demonstrate here persistently increased phosphorylation/activation of GSK3 $\alpha / \beta$ in both acutely and chronically $A \beta$ oligomer-treated $\mathrm{rTg} 4510$ mice. These data would suggest that GSK3 inhibitors may be effective in diminishing some of the effects of $A \beta$ oligomers on exacerbation of tau pathology.

\section{Acknowledgment}

This work was supported by the following NIH grants: AG15490 and NS76308.

\section{Disclosure Statement}

D.M. has had consultancies and/or contracts with the following companies: AstraZeneca, Baxter, Bristol-Myers-Squibb, Chiesi, Eisai, Elan, Ethicon, Forest, Lilly, Lundbeck, Merck, NeuroImmune, NiCox, Pfizer, Rinat and Wyeth. None of these activities pertain to the material presented within this study. The authors have no actual or potential conflicts of interest.

\section{References}

1 Trojanowski JQ, Schmidt ML, Shin RW, Bramblett GT, Rao D, Lee VM: Altered tau and neurofilament proteins in neuro-degenerative diseases: diagnostic implications for Alzheimer's disease and Lewy body dementias. Brain Pathol 1993;3:45-54.

-2 Li B, Chohan MO, Grundke-Iqbal I, Iqbal K: Disruption of microtubule network by Alzheimer abnormally hyperphosphorylated tau. Acta Neuropathol 2007;113:501-511.
3 Konzack S, Thies E, Marx A, Mandelkow EM, Mandelkow E: Swimming against the tide: mobility of the microtubule-associated protein tau in neurons. J Neurosci 2007;27: 9916-9927.

-4 LaPointe NE, Morfini G, Pigino G, Gaisina IN, Kozikowski AP, Binder LI, Brady ST: The amino terminus of tau inhibits kinesin-dependent axonal transport: implications for filament toxicity. J Neurosci Res 2009;87: 440-451.
5 Hutton M, Lendon CL, Rizzu P, Baker M, Froelich S, Houlden H, Pickering-Brown S, Chakraverty S, et al: Association of missense and $5^{\prime}$-splice-site mutations in tau with the inherited dementia FTDP-17. Nature 1998; 393:702-705.

6 Poorkaj P, Bird TD, Wijsman E, Nemens E, Garruto RM, Anderson L, Andreadis A, Wiederholt WC, et al: Tau is a candidate gene for chromosome 17 frontotemporal dementia. Ann Neurol 1998;43:815-825. 
-7 Ramsden M, Kotilinek L, Forster C, Paulson J, McGowan E, SantaCruz K, Guimaraes A, Yue M, et al: Age-dependent neurofibrillary tangle formation, neuron loss, and memory impairment in a mouse model of human tauopathy (P301L). J Neurosci 2005;25: 10637-10647.

8 Santacruz K, Lewis J, Spires T, Paulson J, Kotilinek L, Ingelsson M, Guimaraes A, DeTure $M$, et al: Tau suppression in a neurodegenerative mouse model improves memory function. Science 2005;309:476-481.

-9 Bolmont T, Clavaguera F, Meyer-Luehmann M, Herzig MC, Radde R, Staufenbiel M, Lewis J, Hutton M, et al: Induction of tau pathology by intracerebral infusion of amyloid-beta-containing brain extract and by amyloidbeta deposition in APP $\mathrm{x}$ Tau transgenic mice. Am J Pathol 2007;171:2012-2020.

10 Gotz J, Chen F, van Dorpe J, Nitsch RM: Formation of neurofibrillary tangles in P3011 tau transgenic mice induced by $\mathrm{A} \beta 42$ fibrils. Science 2001;293:1491-1495.

$\checkmark 11$ Oddo S, Caccamo A, Tran L, Lambert MP, Glabe CG, Klein WL, LaFerla FM: Temporal profile of amyloid-beta $(A \beta)$ oligomerization in an in vivo model of Alzheimer disease. A link between $A \beta$ and tau pathology. J Biol Chem 2006;281:1599-1604.

12 Selkoe DJ: Alzheimer's disease is a synaptic failure. Science 2002;298:789-791.

-13 O’Nuallain B, Klyubin I, Mc Donald JM, Foster JS, Welzel A, Barry A, Dykoski RK, Cleary JP, et al: A monoclonal antibody against synthetic $A \beta$ dimer assemblies neutralizes brain-derived synaptic plasticitydisrupting A $\beta$. J Neurochem 2011;119:189201.

-14 Barry AE, Klyubin I, Mc Donald JM, Mably AJ, Farrell MA, Scott M, Walsh DM, Rowan MJ: Alzheimer's disease brain-derived amyloid- $\beta$-mediated inhibition of LTP in vivo is prevented by immunotargeting cellular prion protein. J Neurosci 2011;31:72597263.

15 Gong Y, Chang L, Viola KL, Lacor PN, Lambert MP, Finch CE, Krafft GA, Klein WL: Alzheimer's disease-affected brain: presence of oligomeric A beta ligands (ADDLs) suggests a molecular basis for reversible memory loss. Proc Natl Acad Sci USA 2003;100: 10417-10422.

16 Lesne S, Koh MT, Kotilinek L, Kayed R, Glabe CG, Yang A, Gallagher M, Ashe KH: A specific amyloid-beta protein assembly in the brain impairs memory. Nature 2006;440: 352-357.

17 Rapoport M, Dawson HN, Binder LI, Vitek MP, Ferreira A: Tau is essential to beta-amyloid-induced neurotoxicity. Proc Natl Acad Sci USA 2002;99:6364-6369.

18 Roberson ED, Halabisky B, Yoo JW, Yao J, Chin J, Yan F, Wu T, Hamto P, et al: Amyloid$\beta /$ Fyn-induced synaptic, network, and cognitive impairments depend on tau levels in multiple mouse models of Alzheimer's disease. J Neurosci 2011;31:700-711.
9 Roberson ED, Scearce-Levie K, Palop JJ, Yan F, Cheng IH, Wu T, Gerstein H, Yu GQ, et al: Reducing endogenous tau ameliorates amyloid beta-induced deficits in an Alzheimer's disease mouse model. Science 2007;316:750754.

20 Ittner LM, Ke YD, Delerue F, Bi M, Gladbach A, van Eersel J, Wolfing $\mathrm{H}$, Chieng BC, et al: Dendritic function of tau mediates amyloidbeta toxicity in Alzheimer's disease mouse models. Cell 2010;142:387-397.

-21 Stine WB Jr, Dahlgren KN, Krafft GA, LaDu MJ: In vitro characterization of conditions for amyloid-beta peptide oligomerization and fibrillogenesis. J Biol Chem 2003;278: 11612-11622.

22 Selenica ML, Wang X, Ostergaard-Pedersen L, Westlind-Danielsson A, Grubb A: Cystatin $\mathrm{C}$ reduces the in vitro formation of soluble A $\beta 1-42$ oligomers and protofibrils. Scand J Clin Lab Invest 2007;67:179-190.

23 Carty N, Lee D, Dickey C, Ceballos-Diaz C, Jansen-West K, Golde TE, Gordon MN, Morgan D, et al: Convection-enhanced delivery and systemic mannitol increase gene product distribution of $A A V$ vectors 5,8 , and 9 and increase gene product in the adult mouse brain. J Neurosci Methods 2010;194: 144-153.

24 Craft JM, Watterson DM, Van Eldik LJ: Human amyloid beta-induced neuroinflammation is an early event in neurodegeneration. Glia 2006;53:484-490.

25 Gordon MN, Holcomb LA, Jantzen PT, DiCarlo G, Wilcock D, Boyett KW, Connor K, Melachrino J, et al: Time course of the development of Alzheimer-like pathology in the doubly transgenic PS1+APP mouse. Exp Neurol 2002;173:183-195.

26 LaFerla FM, Oddo S: Alzheimer's disease: $\mathrm{A} \beta$, tau and synaptic dysfunction. Trends Mol Med 2005;11:170-176.

27 Lewis J, Dickson DW, Lin WL, Chisholm L, Corral A, Jones G, Yen SH, Sahara N, et al: Enhanced neurofibrillary degeneration in transgenic mice expressing mutant tau and APP. Science 2001;293:1487-1491.

28 Selenica ML, Jensen HS, Larsen AK, Pedersen ML, Helboe L, Leist M, Lotharius J: Efficacy of small-molecule glycogen synthase kinase-3 inhibitors in the postnatal rat model of tau hyperphosphorylation. Br J Pharmacol 2007;152:959-979.

29 Bramblett GT, Goedert M, Jakes R, Merrick SE, Trojanowski JQ, Lee VM: Abnormal tau phosphorylation at Ser ${ }^{396}$ in Alzheimer's disease recapitulates development and contributes to reduced microtubule binding. Neuron 1993;10:1089-1099.

-30 Lee DC, Rizer J, Selenica ML, Reid P, Kraft C, Johnson A, Blair L, Gordon MN, et al: LPS-induced inflammation exacerbates phospho-tau pathology in rTg4510 mice. J Neuroinflammation 2010;7:56.
Kantarci K, Boeve BF, Wszolek ZK, Rademakers R, Whitwell JL, Baker MJ, Senjem ML, Samikoglu AR, et al: MRS in presymptomatic MAPT mutation carriers: a potential biomarker for tau-mediated pathology. Neurology 2010;75:771-778.

32 Braak H, Thal DR, Ghebremedhin E, Del Tredici K: Stages of the pathologic process in Alzheimer disease: age categories from 1 to 100 years. J Neuropathol Exp Neurol 2011; 70:960-969.

33 Hutton M: Missense and splice site mutations in tau associated with FTDP-17: multiple pathogenic mechanisms. Neurology 2001;56(suppl 4):S21-S25.

34 Hardy J, Selkoe DJ: The amyloid hypothesis of Alzheimer's disease: progress and problems on the road to therapeutics. Science 2002;297:353-356.

35 Geula C, Wu CK, Saroff D, Lorenzo A, Yuan $M$, Yankner BA: Aging renders the brain vulnerable to amyloid beta-protein neurotoxicity. Nat Med 1998;4:827-331.

36 Oddo S, Billings L, Kesslak JP, Cribbs DH, LaFerla FM: A $\beta$ immunotherapy leads to clearance of early, but not late, hyperphosphorylated tau aggregates via the proteasome. Neuron 2004;43:321-332.

37 Wilcock DM, Gharkholonarehe N, Van Nostrand DE, Davis J, Vitek MP, Colton CA: Amyloid reduction by amyloid-beta vaccination also reduces mouse tau pathology and protects from neuron loss in two mouse models of Alzheimer's disease. J Neurosci 2009;29:7957-7965.

- 38 Hoover BR, Reed MN, Su J, Penrod RD, Kotilinek LA, Grant MK, Pitstick R, Carlson GA, et al: Tau mislocalization to dendritic spines mediates synaptic dysfunction independently of neurodegeneration. Neuron 2010;68:1067-1081.

39 Weldon DT, Rogers SD, Ghilardi JR, Finke MP, Cleary JP, O'Hare E, Esler WP, Maggio JE, et al: Fibrillar beta-amyloid induces microglial phagocytosis, expression of inducible nitric oxide synthase, and loss of a select population of neurons in the rat CNS in vivo. J Neurosci 1998; 18:2161-2173.

40 Holcomb LA, Gordon MN, Benkovic SA, Morgan DG: A beta and perlecan in rat brain: glial activation, gradual clearance and limited neurotoxicity. Mech Ageing Dev 2000;112:135-152.

41 Dickey C, Kraft C, Jinwal U, Koren J, Johnson A, Anderson L, Lebson L, Lee D, et al: Aging analysis reveals slowed tau turnover and enhanced stress response in a mouse model of tauopathy. Am J Pathol 2009;174: 228-238.

42 Carty NC, Wilcock DM, Rosenthal A, Grimm J, Pons J, Ronan V, Gottschall PE, Gordon $\mathrm{MN}$, et al: Intracranial administration of deglycosylated C-terminal-specific anti-A $\beta$ antibody efficiently clears amyloid plaques without activating microglia in amyloid-depositing transgenic mice. J Neuroinflammation 2006;3:11. 
43 DiCarlo G, Wilcock D, Henderson D, Gordon M, Morgan D: Intrahippocampal LPS injections reduce $\mathrm{A} \beta$ load in $\mathrm{APP}+\mathrm{PS} 1$ transgenic mice. Neurobiol Aging 2001;22:1007-1012.

44 Herber DL, Mercer M, Roth LM, Symmonds K, Maloney J, Wilson N, Freeman MJ, Morgan $\mathrm{D}$, et al: Microglial activation is required for $A \beta$ clearance after intracranial injection of lipopolysaccharide in APP transgenic mice. J Neuroimmune Pharmacol 2007;2: 222-231.

45 Wilcock DM, DiCarlo G, Henderson D, Jackson J, Clarke K, Ugen KE, Gordon MN, Morgan $\mathrm{D}$ : Intracranially administered anti-A $\beta$ antibodies reduce beta-amyloid deposition by mechanisms both independent of and associated with microglial activation. J Neurosci 2003;23:3745-3751.

46 Zempel H, Thies E, Mandelkow E, Mandelkow EM: $A \beta$ oligomers cause localized $\mathrm{Ca}(2+)$ elevation, missorting of endogenous Tau into dendrites, Tau phosphorylation, and destruction of microtubules and spines. J Neurosci 2010;30:11938-11950.
7 Asuni AA, Hooper C, Reynolds CH, Lovestone S, Anderton BH, Killick R: GSK3 $\alpha$ exhibits $\beta$-catenin and tau directed kinase activities that are modulated by Wnt. Eur J Neurosci 2006;24:3387-3392.

48 Engel T, Lucas JJ, Gomez-Ramos P, Moran MA, Avila J, Hernandez F: Cooexpression of FTDP-17 tau and GSK-3 $\beta$ in transgenic mice induce tau polymerization and neurodegeneration. Neurobiol Aging 2006;27:12581268.

49 Leroy K, Yilmaz Z, Brion JP: Increased level of active GSK-3 $\beta$ in Alzheimer's disease and accumulation in argyrophilic grains and in neurones at different stages of neurofibrillary degeneration. Neuropathol Appl Neurobiol 2007;33:43-55.
50 De Felice FG, Wu D, Lambert MP, Fernandez SJ, Velasco VT, Lacor PN, Bigio EH, Jerecic J, et al: Alzheimer's disease-type neuronal tau hyperphosphorylation induced by A beta oligomers. Neurobiol Aging 2008;29:13341347.

51 Ma QL, Lim GP, Harris-White ME, Yang F, Ambegaokar SS, Ubeda OJ, Glabe CG, Teter $B$, et al: Antibodies against beta-amyloid reduce $A \beta$ oligomers, glycogen synthase kinase- $3 \beta$ activation and tau phosphorylation in vivo and in vitro. J Neurosci Res 2006;83: 374-384.

52 Roberts GW, Gentleman SM, Lynch A, Murray L, Landon M, Graham DI: Beta amyloid protein deposition in the brain after severe head injury: implications for the pathogenesis of Alzheimer's disease. J Neurol Neurosurg Psychiatry 1994;57:419-425.

53 Ransohoff RM, Perry VH: Microglial physiology: unique stimuli, specialized responses. Annu Rev Immunol 2009;27:119-145. 